\title{
Bradykinin-Induced Collapse of Rat Pheochromocytoma (PC12) Cell Growth Cones: A Role for Tyrosine Kinase Activity
}

\author{
Benno Schindelholz and Bernhard F. X. Reber \\ Department of Pharmacology, University of Bern, CH-3010 Bern, Switzerland
}

Pathfinding of growing nerve processes is guided by extracellular guidance cues. Here we report growth cone collapse of NGF-differentiated PC12 cells in culture evoked by the neuropeptide bradykinin. The growth cone response is mediated by $B_{2}$ bradykinin receptors. Two different effects were distinguished. (1) Disappearance of filopodia occurred together with a loss of fibrillar actin (F-actin) in the growth cones at picomolar concentrations of bradykinin. The relative F-actin content was measured by means of rhodamine-phalloidin fluorescence using confocal microscopy. (2) Bradykinin-induced $\mathrm{Ca}^{2+}$ release and retraction of the neurite occurred at nanomolar concentrations. $\mathrm{Ca}^{2+}$ responses at single growth cones were measured using a 1:1 mixture of fura-red and fluo-3 $\mathrm{Ca}^{2+}$-sensitive dyes. The $\left[\mathrm{Ca}^{2+}\right]_{\mathrm{i}}$ rise is not a prerequisite for the observed effects, because $\mathrm{F}$-actin loss and retraction occurred during inhibition of $\mathrm{Ca}^{2+}$ responses. In contrast, inhibition by genistein pointed to a tyrosine kinase activity in the bradykinin-evoked cellular events. Subsequent analysis of phosphotyrosine proteins revealed that bradykinin stimulated tyrosine phosphorylation of the cytoskeleton-associated protein paxillin and the nonreceptor protein tyrosine kinase $\mathrm{pp} 60^{\mathrm{c}-\mathrm{src}}$. Paxillin and $\mathrm{pp} 60^{\mathrm{c}-\mathrm{src}}$ co-precipitated after bradykinin treatment. Immunostaining experiments showed punctate distribution of paxillin along PC12 neurites and in growth cones. Taken together, our data suggest that $\mathrm{pp} 60^{\mathrm{c}-\mathrm{src}}$ and paxillin are putative components of the intracellular signaling pathway of bradykinin-mediated neurite retraction and provide evidence for a crosstalk between Gprotein- and tyrosine kinase-dependent pathways in these cellular events.

Key words: pheochromocytoma cell; growth cone collapse; F-actin; bradykinin; calcium; pp60 ${ }^{c-s r c}$; tyrosine kinase; paxillin
Axonal path finding during neural development is guided by signals that the advancing neurite exchanges with its local environment. A number of growth-promoting, steering, and inhibiting factors have been described so far (for review, see Schwab et al., 1993; Keynes and Cook, 1995; Goodman, 1996; Tessier-Lavigne and Goodman, 1996). Neuronal growth cones constitute the main sites of action for these guiding signals. These highly motile cellular structures are largely independent from direct control of the cell bodies and are important for understanding control of cell shape and motility by extracellular cues. Some of the ligandreceptor systems involved in axon guidance have been reviewed recently (Tessier-Lavigne and Goodman, 1996).

Polypeptide growth factors play an important role in growth, development, maturation, and normal functioning of many vertebrate cell types. The nonapeptide bradykinin is a mediator involved in inflammatory, pain-stimulating, and mitogenic processes. It is a regulatory peptide involved in control of neurotransmission and regulation of cell growth (for review, see Farmer and Burch, 1992). Its influence on axon guidance in vivo has not been established. However, there are reports that show growth cone collapse of NGF-differentiated PC12 cells in vitro (Tigyi et al., 1996).

The initial events in the signal transduction pathway of bradykinin receptors are well known. In intact cells, bradykinin stim-

Received Aug. 8, 1997; accepted Aug. 20, 1997.

This work was supported by Swiss National Science Foundation Grant 4140483.94 to B.F.X.R. We are very grateful to Ms. C. Becker for introducing B Schindelholz to cell culture techniques. We also thank Drs. V. Niggli and K. Baltensperger for careful reading and suggestions on this manuscript.

Correspondence should be addressed to Dr. Bernhard F. X. Reber, Department of Pharmacology, University of Bern, Friedbühlstrasse 49, CH-3010 Bern, Switzerland. Copyright (C) 1997 Society for Neuroscience $0270-6474 / 97 / 178391-11 \$ 05.00 / 0$ ulates phospholipase $\mathrm{C}$, phospholipase A2, adenylate cyclase, and guanylate cyclase (Farmer and Burch, 1992). In addition, the mitogenic activity of bradykinin is attributable to stimulation of a tyrosine phosphorylation pathway activated by the G-proteincoupled receptors (Leeb-Lundberg et al., 1994; Lev et al., 1995; Lee and Villereal, 1996). In Swiss 3 T3 fibroblasts, bradykinin causes protein tyrosine phosphorylation of the focal adhesionassociated proteins pp $125^{\mathrm{FAK}}$ and paxillin. Elevation of intracellular $\mathrm{Ca}^{2+}$ concentration can lead to activation of the mitogenactivated protein (MAP) kinase signaling pathway in rat pheochromocytoma (PC12) cells via the nonreceptor protein tyrosine kinase (PTK) PYK2 (Lev et al., 1995). A crosstalk between the G-protein-coupled receptors and nonreceptor PTKs of the src family has been shown in undifferentiated PC12 cells (Dikic et al., 1996). In addition, tyrosine kinases are involved in the regulation of growth cone steering and cell migration (Pasquale et al., 1992; Goodman, 1996; Holland et al., 1996). A specific function for axonal growth was described for the nonreceptor PTK pp60 ${ }^{\text {c-src }}$, because neurite extension on L1, but not laminin, was impaired in $\mathrm{src}^{-}$cerebellar neurons (Ignelzi et al., 1994).

PC12 cells have been widely used in studies of neuronal cell differentiation (Greene and Tischler, 1976). Here, we demonstrate that bradykinin causes collapse of PC12 growth cones consisting of fibrillar actin (F-actin) loss in the growth cone filopodia and of a small neurite retraction. The bradykininevoked responses are mediated by $\mathrm{B}_{2}$ receptors. We show evidence that the nonreceptor PTK pp60 ${ }^{\mathrm{c}-\mathrm{src}}$ and the adapter protein paxillin are involved in these cellular responses. A preliminary report about the bradykinin-induced F-actin loss has been presented previously (Schindelholz and Reber, 1996). 


\section{MATERIALS AND METHODS}

Cell cultures. All experiments were performed with rat pheochromocytoma (PC12) cells from a clone originally provided by Prof. U. Otten (University of Basel, Basel, Switzerland). This clone was selected for expression of a fast response in NGF-induced differentiation. Cells were differentiated as described previously (Reber et al., 1992). Briefly, cells were plated at a density of 5000 cells $/ \mathrm{cm}^{2}$ either on poly-L-lysine-coated $\left(16 \mu \mathrm{g} / \mathrm{cm}^{2}\right)$ or poly-L-lysine- and laminin-coated $\left(16 \mu \mathrm{g} / \mathrm{cm}^{2}\right.$ plus 1 $\mu \mathrm{g} / \mathrm{cm}^{2}$ ) glass coverslips that were placed in a Petri dish (diameter, 3.2 $\mathrm{cm}$ ) in DMEM supplemented with $10 \%$ horse serum (HS). Morphological differentiation of PC12 cells was induced by reducing the HS concentration to $2.5 \%$ and by adding NGF ( $7 \mathrm{~S}$ fraction, $100 \mathrm{ng} / \mathrm{ml}$ ). The culture medium was replaced every other day. Experiments were performed after 4-5 d NGF-induced differentiation. Cell cultures of human foreskin fibroblasts were kindly provided by Dr. S. Zbinden (University of Bern).

Cell morphology. For analysis of morphological changes, cells were placed on the stage of an inverted microscope (Axiovert 100; Zeiss, Zurich, Switzerland). Cells were kept in a solution consisting of (in mM): $140 \mathrm{NaCl}, 5 \mathrm{KCl}, 1.5 \mathrm{MgCl}_{2}, 2 \mathrm{CaCl}_{2}$, and $10 \mathrm{HEPES}-\mathrm{NaOH}, \mathrm{pH} \mathrm{7.4,}$ diluted 1:1 with culture medium during the experiments performed at room temperature (RT) or at $37^{\circ} \mathrm{C}$. Agonists and inhibitors were added from concentrated stock solutions. The cells were viewed for fluorescence and differential interference contrast (DIC) images with a $40 \times 1.3$ numerical aperture (NA) oil immersion objective (Plan-Neofluar, Zeiss) and with a $40 \times 0.75 \mathrm{NA}$ air objective (Plan-Neofluar) for phase-contrast images, respectively. Cell morphology was recorded by means of the bright-field image channel of a laser scanning microscope (LSM 410, Zeiss).

F-actin staining. For staining of F-actin, cells were fixed for $10 \mathrm{~min}$ in a fresh solution of PBS containing $3.7 \%$ formaldehyde. Lipids were extracted by acetone or ethanol precipitation at $-20^{\circ} \mathrm{C}$. After drying, samples were incubated for $20 \mathrm{~min}$ with rhodamine-conjugated phalloidin (3.3 $\mu \mathrm{M}$ in PBS). The total cell proteins were stained with the general protein dye 5-[4,6-dichlorotriazin-2-yl]aminofluorescein (DTAF). A fresh solution of DTAF [ $1 \%$ in dimethylsulfoxide (DMSO)] was diluted 1000 -fold with PBS and added for $15 \mathrm{~min}$ to the cells prestained with rhodamine-phalloidin. The cells were washed three times with PBS and mounted in a solution of PBS and glycerol (1:1) on a slide glass. They were viewed with a $63 \times 1.3$ NA oil immersion objective (Plan-Neofluar) attached to an inverted microscope (Axiovert 100) that is part of a confocal laser scanning microscope (LSM 410). The DTAF and rhodamine dyes were excited simultaneously with the $488 \mathrm{~nm}$ light beam of an argon laser and the $543 \mathrm{~nm}$ light beam of a neon laser, respectively. Rhodamine-phalloidin fluorescence was measured through a $560 \mathrm{~nm}$ long-pass barrier filter, and DTAF fluorescence was measured through a 510-515 nm interference filter. Care was taken to set identical pinhole sizes, attenuation, gain, and brightness during a set of experiments. No bleed through of DTAF fluorescence into rhodamine fluorescence was detected at the settings used. Images $(256 \times 256$ pixels spanning 13.6 $\mu \mathrm{m}^{2}$ at the image plane) with 8 bit resolution at each emission fluorescence were taken into computer memory [80486 central processing unit, $33 \mathrm{MHz}, 32$ megabyte (MB) host random access memory (RAM), 2.5 MB video RAM, 320 MB hard disk, and Zeiss LSM 410 software, version 3.70]. Resident functions of the LSM software were used to calculate the ratio values of corresponding pixels of the two images. These ratio values represent a relative quantitative measure of actin concentration, because the fluorescence of rhodamine is proportional to the amount of F-actin (Symons and Mitchison, 1991), and the fluorescence of DTAF appears to be proportional to the total amount of protein at the same locations (Sawin et al., 1993). The ratio values were multiplied by 25 and displayed using a 0-255 integer color look-up table.

Calcium measurements. Changes in intracellular free calcium in the growth cones were measured by using two visible light $\mathrm{Ca}^{2+}$-sensitive dyes in combination with confocal microscopy as described in a previous study (Reber and Schindelholz, 1996). Briefly, cells were loaded with a mixture of fura-red and fluo-3 (1:1) (0.5 $\mu \mathrm{M}$ AM esters in $0.2 \%$ DMSO) at $37^{\circ} \mathrm{C}$ for $20 \mathrm{~min}$. Cells were kept at room temperature for $15 \mathrm{~min}$ to allow cleavage of the AM esters to occur. To monitor changes in $\left[\mathrm{Ca}^{2+}\right]_{\mathrm{i}}$, the two fluorescent dyes were excited simultaneously with the $488 \mathrm{~nm}$ light beam of an argon laser. Emission fluorescence was measured through a $520-560 \mathrm{~nm}$ filter (fluo-3) and through a $590 \mathrm{~nm}$ long-pass barrier filter (fura-red), respectively. Resident functions of the LSM software allowed on-line display of ratio values of corresponding pixels of the two images.
Digital data handling. The digital images were stored as 8 or 24 bit red-green-blue tagged image file format files. Data analysis was performed by means of the public domain National Institutes of Health Image software program (written by Wayne Rasband, National Institutes of Health, Bethesda, MD; available electronically via the Worldwide Web at http://rsb.info.nih.gov/nih-image) using an Apple Power Macintosh $8500 / 120$ computer. Hard-copy printouts were made using a Sony UP3000P video color printer. Wherever possible, data are presented as mean \pm SEM. Commercial software was used for graphical representation (Kaleidagraph, Synergy Software) and for statistical analysis (Statview; Abacus Concepts, Calabasas, CA) of the data.

Immunoprecipitation. NGF-differentiated PC12 cells $\left(10^{6}\right)$ were grown on poly-L-lysine-coated plastic Petri dishes (diameter, $100 \mathrm{~mm}$ ). Cells were washed twice with ice-cold PBS containing $150 \mu \mathrm{M}$ sodium orthovanadate. Cells were lysed in $1 \mathrm{ml}$ of ice-cold Triton X-100 lysis buffer (1\% Triton X-100, 10 mm Tris-HCl, pH 7.4, 150 mm NaCl, 1 mm EGTA, $1 \mathrm{~mm}$ EDTA, $10 \mu \mathrm{g} / \mathrm{ml}$ leupeptin, $1 \mathrm{~mm}$ phenylmethylsulfonyl fluoride, $150 \mu \mathrm{M}$ sodium orthovanadate, $0.5 \mathrm{~mm}$ dithiothreitol, and $50 \mathrm{~mm} \mathrm{NaF}$ ). Insoluble material was removed by two centrifugation steps $(14,000 \times g)$ for $5 \mathrm{~min}$ at $4^{\circ} \mathrm{C}$. The supernatants were transferred to fresh tubes for immunoprecipitation. Equal amounts of proteins $(600 \mu \mathrm{g} / \mathrm{ml})$ were incubated for $4 \mathrm{hr}$ at $4^{\circ} \mathrm{C}$ with $1.0 \mu \mathrm{g}$ of monoclonal antibodies preincubated with protein G-Sepharose CL-4B beads (10 $\mu$; Sigma, St. Louis, MO). Beads were collected by centrifugation $(250 \times g)$ for 2 min and washed twice with ice-cold Triton X-100 lysis buffer $(500 \mu \mathrm{l})$ and PBS $(500 \mu \mathrm{l})$ containing $150 \mu \mathrm{M}$ sodium orthovanadate before subjection to Western blot analysis.

Western blot analysis. Proteins were eluted from the beads by boiling in SDS sample buffer $\left(10 \mathrm{~mm} \mathrm{NaH} \mathrm{PO}_{4}, 10 \%\right.$ glycerol, $8 \%$ SDS, $33 \mathrm{~mm}$ dithiothreitol, and $0.13 \mathrm{ng} / \mathrm{ml}$ bromphenol blue) for $5 \mathrm{~min}$ and subjected to SDS-PAGE. The separated proteins were transferred to nitrocellulose membranes (Bio-Rad, Richmond, CA), and nonspecific binding sites were blocked by incubating the membranes in blocking buffer (3\% nonfat dry milk, $500 \mathrm{~mm} \mathrm{NaCl}, 5 \mathrm{~mm}$ Tris-HCl, pH 7.5, and $0.1 \%$ Tween 20). Nonfat dry milk was replaced with $5 \%$ BSA when using the antiphosphotyrosine antibodies. The blots were washed three times with TBS-T (5 mM Tris-HCl, pH 7.5, $150 \mathrm{~mm} \mathrm{NaCl}$, and $0.1 \%$ Tween 20) and probed with horseradish peroxidase-conjugated recombinant antiphosphotyrosine antibody $\operatorname{RC} 20$ (1:2500, 2 hr), anti-paxillin (1:5000, 2 hr) and anti-v-src $(1: 2500,2 \mathrm{hr})$ in TBS-T containing 1\% BSA. After washing three times with TBS-T, anti-mouse IgG conjugated to horseradish peroxidase $(1: 5000,1 \mathrm{hr})$ in TBS-T containing 1\% BSA was added to paxillin and v-src blots. The blots were washed three times with TBS-T and subjected to enhanced chemiluminescence (ECL). The developed ECL films were scanned for quantification using a CAMAG (Basel, Switzerland) TLC Scanner II.

Materials. Tissue culture reagents were purchased from Life Technologies (Basel, Switzerland), and NGF-7S was purchased from Sigma. Bradykinin and its derivatives were obtained from Bachem (Bubendorf, Switzerland). Fluorescent compounds and thapsigargin were purchased from Molecular Probes (Eugene, OR). Recombinant anti-phosphotyrosine antibodies conjugated to horseradish peroxidase (RC20), anti-paxillin antibodies, and horseradish peroxidase-conjugated anti-mouse IgG were purchased from Transduction Laboratories (Lexington, KY). Anti-v-src antibodies were purchased from Oncogene Science. ECL kits were from Amersham (Buckinghamshire, UK). All other chemicals were obtained from Fluka (Buchs, Switzerland).

\section{RESULTS}

\section{Bradykinin-induced growth cone collapse}

The culturing of PC12 cells in the presence of NGF led to formation of neurites within 3-4 d. The neurites extended from a few micrometers to several tenths of micrometers after $4 \mathrm{~d}$. Growth cones (Fig. $1 A$ ) were visible at the distal end of extending neurites, showing a similar morphology with moving filopodia and varicosities as described by Aletta and Greene (1988). The PC12 cell growth cones lost their filopodia after bath application of 50 pM bradykinin within minutes. At higher concentrations (500 nM), bradykinin evoked stronger growth cone collapse together with retraction of the neurites within a short period, as analyzed by time-lapse image recording using a confocal microscope (Fig. 1B) equipped with DIC optics. Neurite retraction 


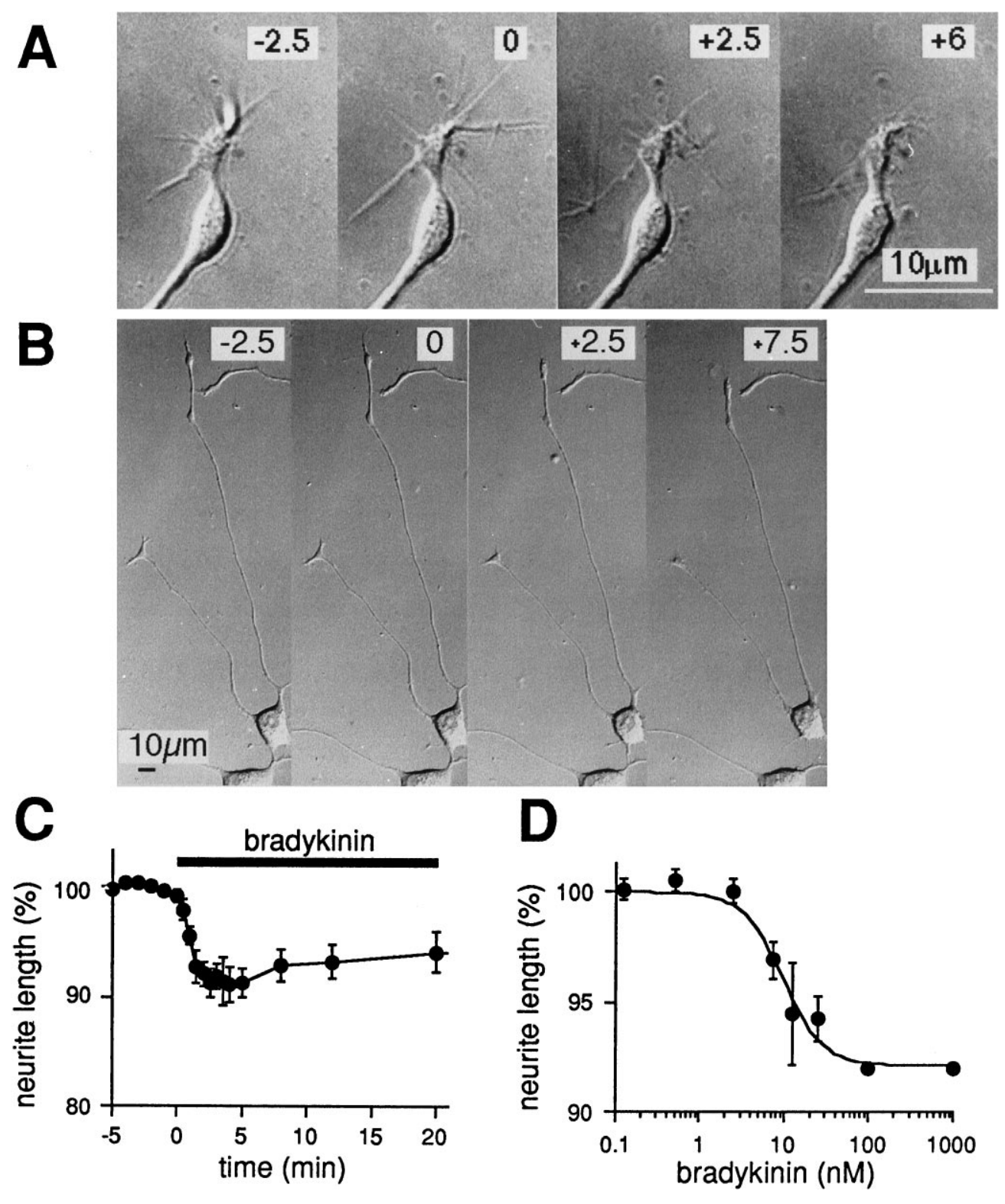

Figure 1. Bradykinin-induced growth cone collapse of NGF-differentiated PC12 cells in culture. Video time-lapse recordings were performed on PC12 cells during bath application of bradykinin as described in Materials and Methods. $A$, Morphology of a PC12 cell growth cone viewed at $2000 \times$ magnification in the presence of $50 \mathrm{pm}$ bradykinin at RT for the time (minutes) indicated (top right). Collapse of the F-actin-containing filopodia was observed within minutes. The varicosity remained at its initial position. $B$, Morphology of a PC12 cell viewed at $300 \times$ magnification with extending neurites during stimulation with $500 \mathrm{~nm}$ bradykinin at RT. Initial filopodia are lost, and the neurite retracts and stretches a little. $C$, Time course of bradykinininduced growth cone retraction. Bradykinin was applied to NGF-differentiated PC12 cells kept in HEPES-buffered culture medium at RT. The length of individual neurites was measured on digitized pictures. The mean neurite length $(n=24)$ is plotted against time. Halfmaximal retraction was after $50 \mathrm{sec}$. The maximal shortening of the neurites was $7.9 \pm 1.2 \%$. D , Dose-response relationship of bradykinin-induced neurite retraction. The mean neurite length $(n=$ 5) was measured on digitized pictures after a 5 min exposure to increasing concentrations of bradykinin. The $\mathrm{EC}_{50}$ value $(9.6 \mathrm{nM})$ was calculated by nonlinear fitting of the data to the equation $E=$ $100\left(1-\right.$ [bradykinin $^{n} /$ [bradykinin $^{n}+$ $\mathrm{EC}_{50}^{n}$ ) (Cachelin and Rust, 1994). became detectable 0.5 min after the addition of bradykinin and was completed within 4-5 min (Fig. 1C). On average, neurite length decreased by $7.9 \pm 1.2 \%(n=24 ; p<0.001)$ because of bradykinin treatment when compared with nontreated controls. This reduction in neurite length was similar to that in a recent report in which $10 \mu \mathrm{M}$ bradykinin caused a $4.6 \pm 4.8 \%$ decrease (Tigyi et al., 1996). A partial regrowth of neurites occurred within the following hour. Growth cone collapse was half-maximal at 9.7 nм bradykinin (Fig. 1D). When bradykinin was applied focally as a puff from a glass micropipette to a well developed growth cone, it evoked collapse of this growth cone. Nearby growth cones did not respond (data not shown). This result argues for bradykinin receptor localization in growth cones.

\section{Bradykinin-induced F-actin loss in growth cone filopodia}

Filopodia that are extending from advancing growth cones act like antennae by transducing environmental signals into cellular responses (Goodman, 1996). The supporting structure of these filopodia consists of densely bundled F-actin (Challacombe et al.,
1996). Figure $2 A$ shows two separate growth cones before and after $50 \mathrm{~nm}$ bradykinin addition observed by phase contrast optics and by fluorescence of rhodamine-conjugated phalloidin (RP)stained F-actin, respectively. Bradykinin-induced loss of filopodia correlates with the reduced F-actin stain.

To estimate further the quantitative distribution of F-actin in growth cones during bradykinin-induced collapse, we applied a procedure originally described by Fan et al. (1993). F-actincontaining structures of the cells were stained with RP. The spatial distribution of the fluorescence intensity in the growth cone area was measured digitally by laser scanning microscopy. The fluorescence intensity of RP was correlated with the fluorescence intensity of DTAF, a general protein marker (Sawin et al., 1993). The fluorescence images of both dyes and the corresponding ratio image are shown in Figure $2 B$. The RP fluorescence is much brighter in the filopodia than in the growth cone center revealing a high F-actin content in these structures. The DTAF fluorescence indicates the distribution of total protein, being high in the center and low in the filopodia. These two images were 
Figure 2. Quantification of F-actin in single growth cones. $A$, Bradykinininduced loss of growth cone filopodia. $a$, Example of a fixed growth cone seen by phase-contrast optics. $b$, Same growth cone as in $a$ stained for F-actin with rhodamine phalloidin. The F-actin stain correlates with intact filopodia structure, $c$, Second control growth cone in culture medium. $d$, Same growth cone as in $c$ after bradykinin (Bk) treatment (50 nM, $5 \mathrm{~min}$ ) and cell fixation. $e$, Rhodamine phalloidin stain of bradykinintreated growth cone. Note that the loss of filopodia correlates with the loss of F-actin stain. Scale bar, $5 \mu \mathrm{m}$. B, Confocal image planes of a double-labeled PC12 growth cone. Formaldehyde-fixed cells were stained for F-actin with RP and for total protein with DTAF and were viewed by means of confocal microscopy. The ratio image represents a pixel-by-pixel division of the RP image by the DTAF image multiplied by 25 to be displayed using the black-and-white intensity look-up-table as shown. $C$, Calculation of the r.a.c. per growth cone. A control and a bradykinintreated $(25 \mathrm{nM}, 5 \mathrm{~min})$ growth cone are shown. The region of interest was defined by an area mask (black area) of $\sim 1700$ pixels (intensity, $>5$ ). The numbers (bottom right) indicate the size of the area mask in pixels and the calculated mean intensities, respectively. $D$, F-actin distribution in PC12 growth cones of control and bradykinin-treated cells $(25 \mathrm{nM}, 5 \mathrm{~min})$. The numbers (bottom right) indicate calculated mean intensities using a mask size of $\sim 1700$ pixels. $E$, Statistical analysis of the r.a.c. of control and bradykinin-treated cells $(n=12 ; p<0.0001) . F$, Time course of the bradykinin-evoked r.a.c. change. Cells were incubated with $25 \mathrm{~nm}$ bradykinin for various lengths of time. The experiment was performed at RT ( filled circles, $t_{1 / 2} \approx 1 \mathrm{~min}$ ), $4^{\circ} \mathrm{C}$ (open circles, $t_{1 / 2} \approx 3 \mathrm{~min}$ ), and without bradykinin at $4^{\circ} \mathrm{C}$ ( filled squares). Basal r.a.c. recovered during the continuous presence of bradykinin ( filled circle). Each data point represents the mean $\pm \operatorname{SEM}(n=$ 12). $G$, Dose-response relationship of bradykinin-induced decrease in r.a.c. $\left(\mathrm{EC}_{50}=1.6 \mathrm{pM}\right)$.
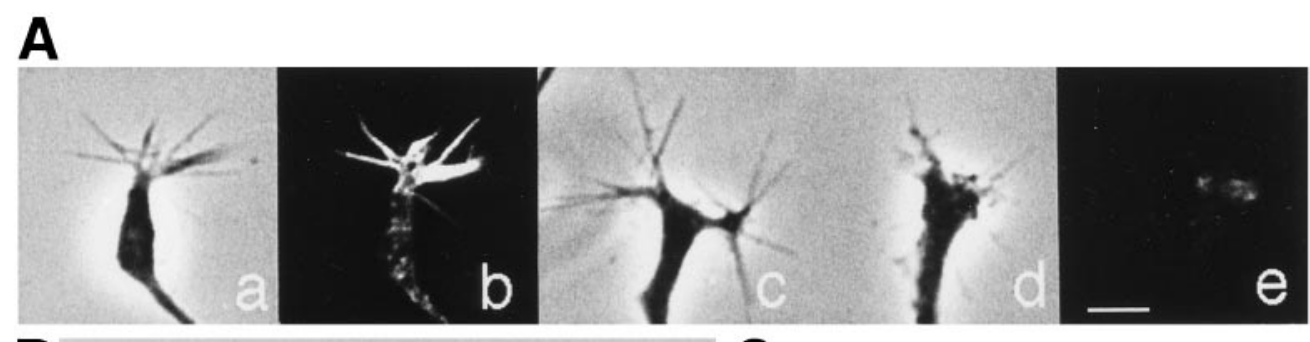

B
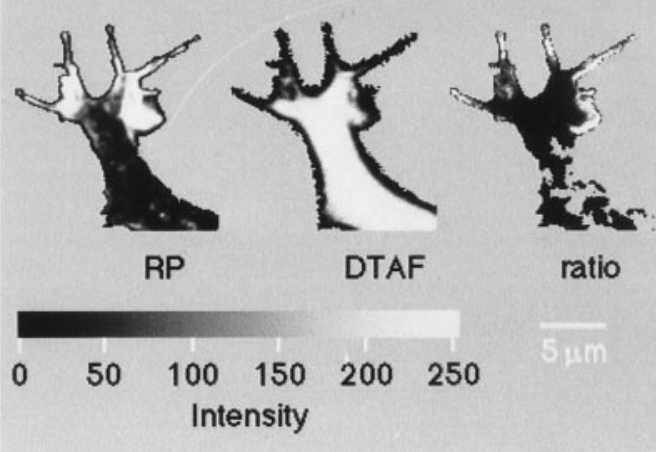

C

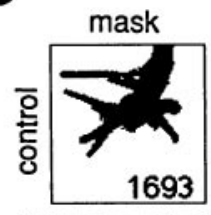

Ratio
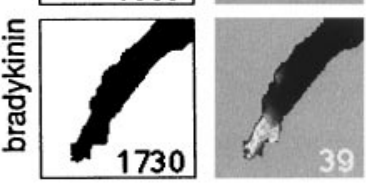

D
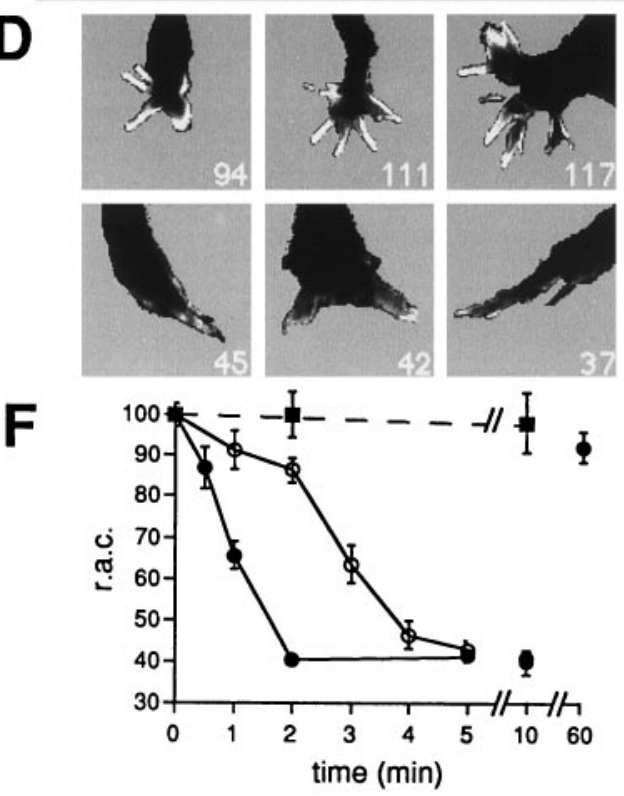

G
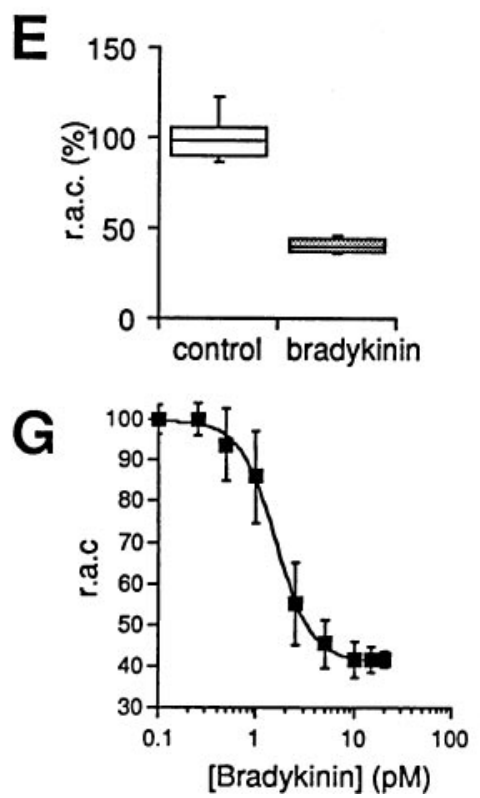

divided pixel by pixel to obtain a ratio image that was used to estimate the relative actin content in growth cone areas (Fig. 2C). Area masks of almost equal size were defined at an intensity threshold of $>5$ before averaging. Although the size of filopodia was variable among individual growth cones (Fig. 2D) (Okabe and Hirokawa, 1991), the ratio values represented a valid measure for the relative $\mathrm{F}$-actin content per growth cone area (r.a.c.). The r.a.c. of nonstimulated growth cones kept under normal culture conditions was set to $100 \%$. Treatment of PC12 cells with bradykinin $(25 \mathrm{nM}, 2 \mathrm{~min}, \mathrm{RT})$ reduced the r.a.c. in growth cones to $43 \pm 2 \%(n=12)$ (Fig. $2 E)$. The half-rate of bradykinin-induced loss of F-actin in growth cones was $1 \mathrm{~min}$ at RT (Fig. $2 F$ ). The reaction rate was reduced at lower temperature $\left(t_{1 / 2}=3 \mathrm{~min}\right.$ at $4^{\circ} \mathrm{C}$ ). Keeping the cells at $4^{\circ} \mathrm{C}$ in the absence of bradykinin caused no detectable filopodial F-actin loss. The analysis of the dose- response relationship showed a very high potency for bradykinin to evoke a decrease of F-actin content in growth cones $\left(\mathrm{EC}_{50}=\right.$ $1.6 \mathrm{pM}$ ) (Fig. 2G). Bradykinin is effective at picomolar concentrations like collapsin-I, which induces collapse of neuronal growth cones of chick dorsal root ganglion cells (Luo et al., 1993). However, the bradykinin concentration initiating F-actin loss is $\sim 1000$-fold smaller than the concentration releasing $\mathrm{Ca}^{2+}$ from intracellular $\mathrm{Ca}^{2+}$ stores (see below).

\section{Pharmacology of bradykinin-induced growth cone collapse}

Two types of bradykinin receptors, $B_{1}$ and $B_{2}$, have been characterized pharmacologically in various tissues (Farmer and Burch, 1992). $B_{2}$ receptors are expressed constitutively in many tissues, whereas $B_{1}$ receptors are expressed in very low numbers 
Table 1. Effects of bradykinin derivatives of F-actin content in PC12 growth cones

\begin{tabular}{|c|c|c|c|c|}
\hline & Receptor specificity & Concentration & Bradykinin (5 pM) & r.a.c. $(\%)$ \\
\hline Control & & & - & $100 \pm 4$ \\
\hline \multicolumn{5}{|l|}{ Agonists } \\
\hline \multirow[t]{2}{*}{ Bradykinin } & $\mathrm{B} 1 \ll \mathrm{B} 2$ & $0.25 \mathrm{pm}$ & - & $99 \pm 4$ \\
\hline & & $10 \mathrm{pm}$ & - & $42 \pm 4$ \\
\hline \multirow[t]{2}{*}{ Lys-bradykinin } & $\mathrm{B} 1 \ll \mathrm{B} 2$ & $1 \mathrm{pm}$ & - & $100 \pm 4$ \\
\hline & & $10 \mathrm{pm}$ & - & $43 \pm 3$ \\
\hline \multirow[t]{2}{*}{$\left(\right.$ Des-Arg $\left.{ }^{9}\right)$-bradykinin } & $\mathrm{B} 1 \gg \mathrm{B} 2$ & $500 \mathrm{~nm}$ & - & $101 \pm 4$ \\
\hline & & $50 \mu \mathrm{M}$ & - & $68 \pm 3$ \\
\hline \multicolumn{5}{|l|}{ Antagonists } \\
\hline \multirow[t]{2}{*}{$\left(\mathrm{D}-\mathrm{Phe}^{7}\right)$-bradykinin } & $\mathrm{B} 2$ & $1 \mu \mathrm{M}$ & + & $61 \pm 3$ \\
\hline & & $5 \mu \mathrm{M}$ & + & $102 \pm 4$ \\
\hline \multirow[t]{4}{*}{$\left(\beta\right.$-(2-Thienyl)-Ala $\left.{ }^{5,8}, \mathrm{D}-\mathrm{Phe}^{7}\right)$-bradykinin } & $\mathrm{B} 2$ & $1 \mathrm{nM}$ & + & $48 \pm 2$ \\
\hline & & $5 \mathrm{nM}$ & + & $99 \pm 2$ \\
\hline & & $1 \mu \mathrm{M}$ & - & $101 \pm 4$ \\
\hline & & $3 \mu \mathrm{M}$ & - & $86 \pm 2$ \\
\hline \multicolumn{5}{|l|}{ (1-Adamantanecarbonyl-D-Arg ${ }^{0}, \mathrm{Hyp}^{3}$, } \\
\hline$\beta$-(2-Thienyl)-Ala $\left.{ }^{5,8}, \mathrm{D}-\mathrm{Phe}^{7}\right)$-bradykinin & B2 & $1 \mathrm{~nm}$ & + & $99 \pm 4$ \\
\hline$\left(\mathrm{D}-\mathrm{Arg}^{0}, \mathrm{Hyp}^{2,3}, \mathrm{D}-\mathrm{Phe}^{7}\right)$-bradykinin & B1, B2 & $2 \mu \mathrm{M}$ & + & $103 \pm 5$ \\
\hline
\end{tabular}

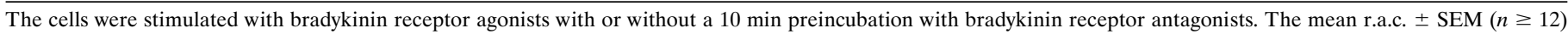
are shown.

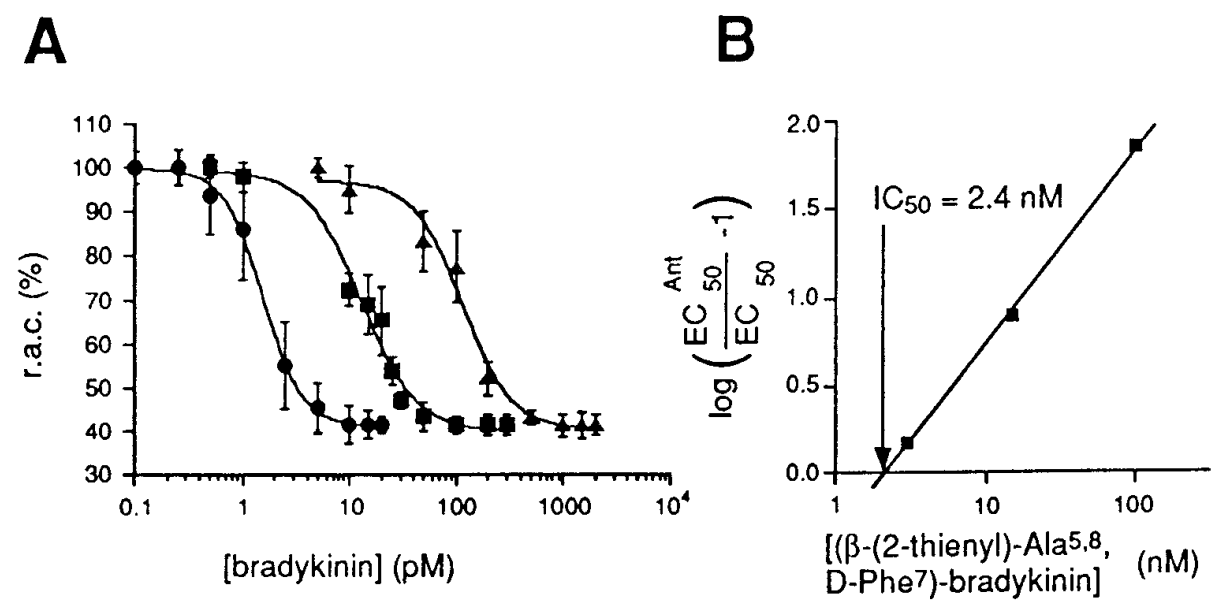

Figure 3. Antagonism of bradykinin-induced F-actin loss by $\left(\beta\right.$-(2-thienyl)-Ala ${ }^{5,8}, \mathrm{D}^{\left.-\mathrm{Phe}^{7}\right)}$ bradykinin. $A$, Inhibition of F-actin loss. Cells were pretreated for $10 \mathrm{~min}$ without (circles) or with $15 \mathrm{nM}$ (squares) and $100 \mathrm{nM}$ (triangles) $\left(\beta\right.$-(2-thienyl)-Ala $\left.{ }^{5,8}, \mathrm{D}-\mathrm{Phe}^{7}\right)$-bradykinin before the addition of bradykinin for 2 min. The r.a.c. was determined by means of confocal imaging as described in Materials and Methods and plotted against bradykinin concentration. $B$, Schild plot analysis was obtained at a response level of $50 \%$ in the presence of 5,15 , and $100 \mathrm{~nm}$ antagonist $\left(\mathrm{IC}_{50}=2.4 \mathrm{nM}\right)$. or not at all under nonpathological conditions. The main physiological agonists at the $\mathrm{B}_{2}$ receptors are bradykinin and kallidin (Lys-bradykinin), which are equipotent. Enzymatic removal of the $\mathrm{C}$-terminal arginine from these agonists generates (des$\operatorname{Arg}^{9}$ )-bradykinin and (des-Arg ${ }^{10}$ )-kallidin, which are preferred agonists at the $\mathrm{B}_{1}$ receptors.

For pharmacological classification of the bradykinin receptor subtype involved in growth cone collapse, several bradykinin derivatives were tested for their agonistic or antagonistic potencies to evoke F-actin loss, respectively (Table 1). Both bradykinin and kallidin induced loss of filopodial F-actin at picomolar concentrations. By contrast, the $\mathrm{B}_{1}$ agonist (des-Arg ${ }^{9}$ )-bradykinin showed a stimulatory activity only at concentrations $>50 \mu \mathrm{M}$. These results argue for $B_{2}$ receptor activity.

The involvement of $B_{2}$ receptors was further established by analysis of the effects of three $B_{2}$ receptor antagonists, i.e., (DPhe $^{7}$ )-bradykinin, ( $\beta$-(2-thienyl)-Ala ${ }^{5,8}, \mathrm{D}-\mathrm{Phe}^{7}$ )-bradykinin (Steranka et al., 1989), and (1-adamantanecarbonyl-D-Arg ${ }^{0}, \mathrm{Hyp}^{3}$, $\mathrm{Thi}^{5,8}, \mathrm{D}-\mathrm{Phe}^{7}$ )-bradykinin (Lammek et al., 1991), respectively. No intrinsic agonistic effects were detected at nanomolar concentra- tions of the antagonists. ( $\beta$-(2-Thienyl)-Ala $\left.{ }^{5,8}, \mathrm{D}-\mathrm{Phe}^{7}\right)$-bradykinin antagonized the effects of bradykinin in a concentration-dependent manner without attenuating the maximal response (Fig. 3). Analysis according to Schild (1947) revealed that ( $\beta$-(2-thienyl)$\left.\mathrm{Ala}^{5,8}, \mathrm{D}-\mathrm{Phe}^{7}\right)$-bradykinin is a competitive antagonist of the bradykinin-induced F-actin loss ( $\mathrm{IC}_{50}$ value, $2.4 \mathrm{~nm}$; $\left.\mathrm{pA}, 8.62\right)$.

The initial events of the bradykinin response in PC12 cells consist of G-protein-coupled formation of inositol trisphosphate $\left(\mathrm{IP}_{3}\right)$ followed by a transient intracellular $\mathrm{Ca}^{2+}$ release (Fasolato et al., 1988; Reber et al., 1992). Bradykinin-evoked $\mathrm{Ca}^{2+}$ responses were measured in single $\mathrm{PC} 12$ growth cones by means of confocal microscopy (Fig. 4). The $\mathrm{Ca}^{2+}$ release in the growth cones was transient $(\sim 2-3 \mathrm{sec})$ at high agonist concentrations and preceded the morphological changes in PC12 growth cones by several seconds (see Fig. 1C). Bradykinin induced intracellular $\mathrm{Ca}^{2+}$ release and growth cone retraction with similar potencies $\left(\mathrm{EC}_{50}=8.1\right.$ and $9.6 \mathrm{nM}$, respectively; Fig. 1$)$. The concentration of $\left(\beta\right.$-(2-thienyl)-Ala $\left.{ }^{5,8}, \mathrm{D}-\mathrm{Phe}^{7}\right)$-bradykinin required to inhibit $\mathrm{Ca}^{2+}$ release was higher than the concentration to inhibit F-actin loss $\left(\mathrm{IC}_{50}=58\right.$ nM; Fig. $4 C$, compared with 2.4 nм; Fig. $\left.3 B\right)$. 


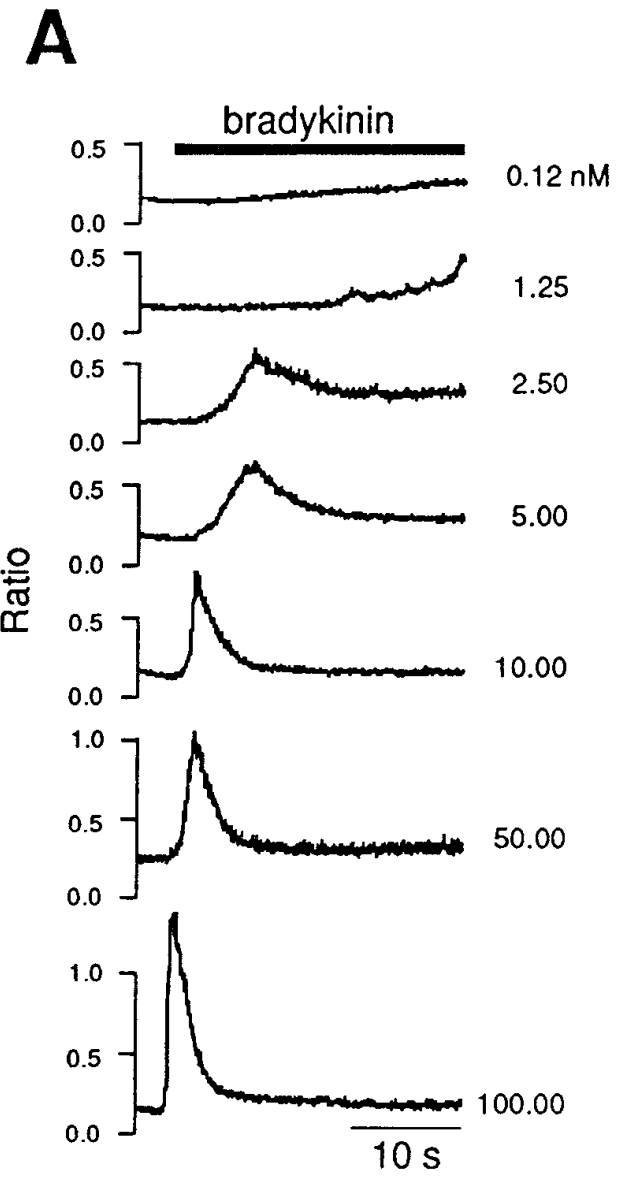

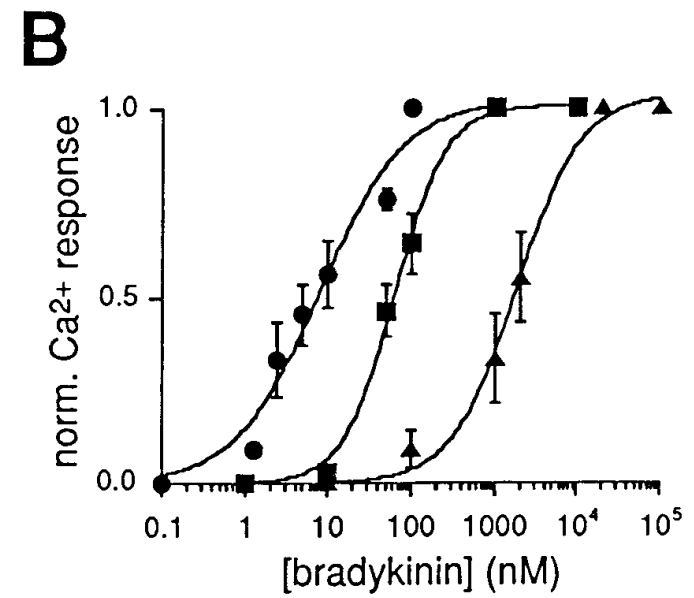

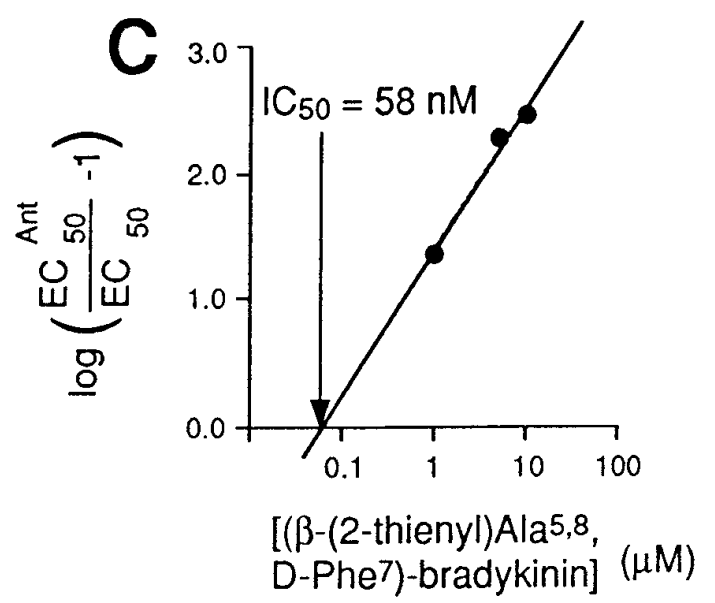

Figure 4. Antagonism by ( $\beta$-(2-thienyl)-Ala $\left.{ }^{5,8}, \mathrm{D}-\mathrm{Phe}^{7}\right)$-bradykinin of bradykinin-induced $\mathrm{Ca}^{2+}$ release. $A$, Bradykinin-induced $\mathrm{Ca}^{2+}$ release in $\mathrm{PC} 12$ growth cones. Cells were stimulated with bradykinin as indicated. $\mathrm{Ca}^{2+}$ responses were measured in growth cones in line-scanning mode at $25 \mathrm{~Hz}$. A representative $\mathrm{Ca}^{2+}$ response is shown for each agonist concentration. $B$, Antagonism of bradykinin-induced Ca ${ }^{2+}$ release by $\left(\beta-\left(2\right.\right.$-thienyl)-Ala ${ }^{5,8}, \mathrm{D}-$ $\left.\mathrm{Phe}^{7}\right)$-bradykinin. PC12 cells were stimulated by bradykinin in the presence of $\left(\beta\right.$-(2-thienyl)-Ala $\left.{ }^{5,8}, \mathrm{D}-\mathrm{Phe}^{7}\right)$-bradykinin. $\mathrm{Ca}^{2+}$ responses were measured in single growth cones without (circles) or at $1 \mu \mathrm{M}$ (squares) and $10 \mu \mathrm{M}$ (triangles) antagonist concentration. Each data point represents the mean response of three growth cones. $C$, Schild plot analysis was obtained at a $\mathrm{Ca}^{2+}$ response level of $50 \%$ in the presence of 1,5 , and $10 \mu \mathrm{M}$ antagonist $\left(\mathrm{IC}_{50}=58 \mathrm{nM}\right)$.

Video time-lapse recordings showed that the $\mathrm{B}_{2}$ antagonist $(500$ $\mathrm{nM}$ ) inhibited bradykinin-induced growth cone collapse (data not shown). Therefore, F-actin loss, $\mathrm{Ca}^{2+}$ release, and growth cone retraction are mediated by $\mathrm{B}_{2}$ receptors.

\section{Effects of $\left[\mathrm{Ca}^{2+}\right]_{\mathrm{i}}$ rise in PC12 growth cones on filopodial F-actin}

The stability of filopodial F-actin can be altered under conditions that change $\left[\mathrm{Ca}^{2+}\right]_{\mathrm{i}}$ (Lankford and Letourneau, 1989; Neely and Gesemann, 1994). For comparison with the bradykinin-induced $\mathrm{F}$-actin loss, we verified the destabilizing effect of $\left[\mathrm{Ca}^{2+}\right]_{\mathrm{i}}$ changes on filopodial F-actin. We applied various stimuli known to elicit $\mathrm{Ca}^{2+}$ responses in $\mathrm{PC} 12$ growth cones. $\mathrm{K}^{+}$-evoked depolarization (70 mM, $2 \mathrm{~min}$ ) (Reber and Reuter, 1991) caused a 50\% loss of r.a.c. (Fig. $5 A$ ). Video time-lapse recordings revealed no neurite retraction similar to bradykinin under these conditions (data not shown). $\mathrm{K}^{+}$-evoked depolarization $\left(70 \mathrm{~mm}\left[\mathrm{~K}^{+}\right]_{\mathrm{o}}\right)$ in $\left[\mathrm{Ca}^{2+}\right]_{\mathrm{o}}$-free medium did not destabilize F-actin (Fig. $5 B$, left). However, the r.a.c. was reduced after readdition of $\mathrm{Ca}^{2+}$ to the external medium of depolarized cells, allowing $\mathrm{Ca}^{2+}$ entry through voltage-gated $\mathrm{Ca}^{2+}$ channels. When ATP was applied extracellularly, F-actin decreased to $55-60 \%$ because of $\mathrm{Ca}^{2+}$ influx (Reber et al., 1992). These experiments indicate that increased $\left[\mathrm{Ca}^{2+}\right]_{\mathrm{i}}$ levels in PC12 growth cones destabilize F-actin.

Is the transient $\left[\mathrm{Ca}^{2+}\right]_{\mathrm{i}}$ rise an obligatory signal in the bradykinin-evoked growth cone collapse? To test this question, intracellular $\mathrm{Ca}^{2+}$ stores involved in the bradykinin-evoked $\mathrm{Ca}^{2+}$ release were emptied by addition of the plant alkaloid thapsigargin, which inhibits the $\mathrm{Ca}^{2+}$-ATPases of the $\mathrm{Ca}^{2+}$ stores (Thastrup et al., 1990). Addition of $400 \mathrm{~nm}$ thapsigargin caused a $55 \% \mathrm{~F}$-actin loss in nominally $\mathrm{Ca}^{2+}$-free medium (Fig. $5 A$, right). After $90 \mathrm{~min}$, however, growth cones had recovered, showing an r.a.c. like that of untreated cells (Fig. 5B, middle). Thapsigargin-treated cells ( $>90 \mathrm{~min}$ ) showed no bradykininevoked $\mathrm{Ca}^{2+}$ release (not shown), but the bradykinin-evoked loss of filopodial F-actin was still observed. In another experiment (Fig. 5B, right), bradykinin caused F-actin loss in cells that had been pretreated with the $\mathrm{Ca}^{2+}$ chelator 1,2-bis(2-aminophenoxy)ethane-tetra-acetic acid (BAPTA AM, $1 \mu \mathrm{M}, 20 \mathrm{~min}$, $37^{\circ} \mathrm{C}$ ) (Reber and Schindelholz, 1996) to block the transient $\left[\mathrm{Ca}^{2+}\right]_{\mathrm{i}}$ rise. Video time-lapse recordings showed that bradykinin-induced neurite retraction was similar between thapsigargin-treated $(12 \pm 2 \%)$ and BAPTA AM-treated $(7 \pm$ 
A

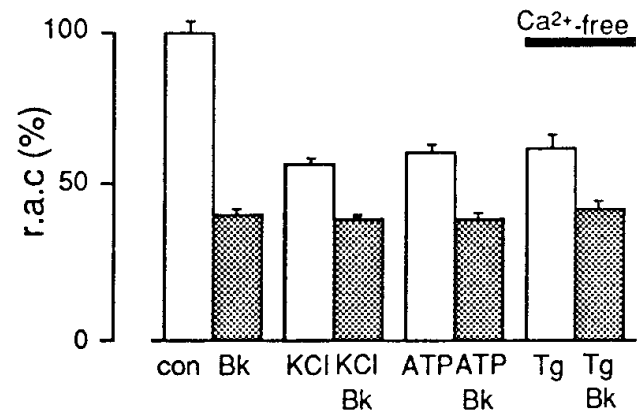

B

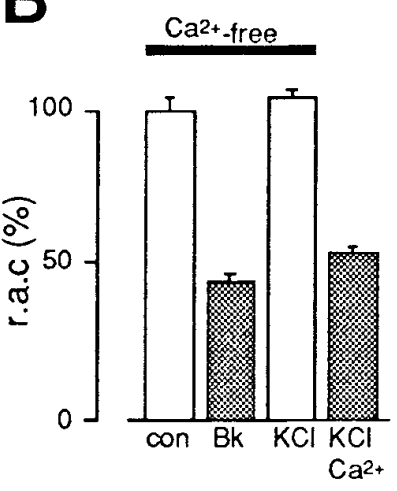

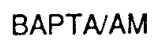
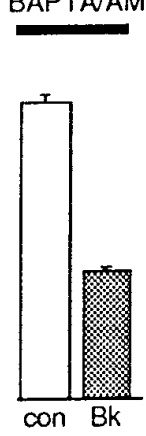

Figure 5. Dependence of F-actin on $\left[\mathrm{Ca}^{2+}\right]_{\mathrm{i}} . A$, Decrease of growth cone $\mathrm{F}$-actin during agonist-induced $\left[\mathrm{Ca}^{2+}\right]_{\mathrm{i}}$ increase. PC12 cells were stimulated as indicated below each bar. Fixed cells were double-stained, and the r.a.c. was measured in single growth cones $(n=12)$. con, Control; $B k, 25$ nM bradykinin, $2 \mathrm{~min} ; K C l, 70 \mathrm{mM}, 2 \mathrm{~min} ; A T P, 10 \mu \mathrm{M}, 2 \mathrm{~min} ; \mathrm{Tg}, 400 \mathrm{~nm}$ thapsigargin, $10 \mathrm{~min} . B$, Decrease of F-actin in growth cone areas in the absence of $\left[\mathrm{Ca}^{2+}\right]_{\mathrm{i}}$ increase. PC12 cells were stimulated by bath application of different stimuli in $\left[\mathrm{Ca}^{2+}\right]_{\mathrm{o}}$-free solution as indicated by the horizontal bars. BAPTA AM, Cells were preincubated with $1 \mu \mathrm{M}$ cellpermeable ester of BAPTA for $30 \mathrm{~min}$. con, Control; $B k$, bradykinin, 25 nM; $\mathrm{KCl}, 70 \mathrm{~mm} ; \mathrm{KCl}-\mathrm{Ca}^{2+}$, readdition of $\left.2 \mathrm{~mm}^{2} \mathrm{Ca}^{2+}\right]_{\mathrm{o}}$ to depolarized cells in $70 \mathrm{~mm}\left[\mathrm{~K}^{+}\right]_{\mathrm{o}} ; \mathrm{Tg}$, cells were incubated with $400 \mathrm{~nm}$ thapsigargin for $90 \mathrm{~min}$ before addition of bradykinin $(25 \mathrm{nM})$. During this time filopodia recovered from the initial thapsigargin-evoked effects (see $A$, right columns).

$2 \%)$ cells. These data argue for $\mathrm{Ca}^{2+}$-independent signal transduction pathways in bradykinin-induced growth cone collapse. A similar finding has been described for collapsin-I-mediated growth cone collapse of chick dorsal root ganglion cells in culture (Ivins et al., 1991)

\section{Crosstalk with tyrosine kinases}

Addition of the general protein kinase inhibitor staurosporine $(100 \mathrm{nM})$ affected growth cone shape, as seen by smaller filopodia (data not shown). Preincubation of the cells with staurosporine $(100 \mathrm{~nm}, 10 \mathrm{~min})$ diminished the r.a.c. $(87.5 \pm 3.3 ; n=12)$. Subsequent addition of bradykinin ( $25 \mathrm{~nm})$ evoked no additional F-actin loss (r.a.c. $=91.8 \pm 3.4 ; n=12$ ). This argues that staurosporine inhibits intrinsic basal protein kinase activity, being involved in growth cone behavior.

Because tyrosine phosphorylation has been implicated in the action of bradykinin in fibroblasts (Leeb-Lundberg et al., 1994; Lee and Villereal, 1996) and in undifferentiated PC12 cells (Lev et al., 1995), we tested whether genistein, a broad-spectrum ty-

rosine kinase inhibitor (Akiyama et al., 1987), blocked bradykinin-induced changes in morphology. Analysis of PC12 cell growth cones incubated for $15 \mathrm{~min}$ at $37^{\circ} \mathrm{C}$ with $100 \mu \mathrm{M}$ genistein did not reveal a detectable loss of filopodia and F-actin (Fig. 6A, $a-d$ ). The same holds true when cells were viewed on the microscope stage for $10 \mathrm{~min}$ at RT in HEPES-buffered culture medium plus $100 \mu \mathrm{M}$ genistein. Genistein $(100 \mu \mathrm{M})$ itself did not affect the neurite length during that time (Fig. 6B, open squares). However, bradykinin-induced neurite retraction was inhibited when cells have been preincubated with the drug $(100 \mu \mathrm{M}, 10 \mathrm{~min}$, $37^{\circ} \mathrm{C}$ ) (Fig. 6B, open circles, $C$ ). F-actin loss was blocked in the presence of $100 \mu \mathrm{M}$ genistein (Fig. $6 A, e, f, D$ ) at both agonist concentrations. By contrast, the dihydroxy analog of genistein, daidzein $(100 \mu \mathrm{M})$, lacking the ability to regulate tyrosine kinases, was ineffective.

Immunoblotting was used to evaluate bradykinin-induced changes in the distribution of phosphotyrosine proteins. NGFinduced changes in the tyrosine phosphorylation pattern of undifferentiated PC12 cells were used to establish Western blotting with an anti-phosphotyrosine antibody (Khan et al., 1995). The major proteins phosphorylated in response to NGF after $15 \mathrm{~min}$ were 43, 46, and $60 \mathrm{kDa}$ (Fig. 7A, left lanes). By comparison, bradykinin was a weaker stimulus of tyrosine phosphorylation in NGF-differentiated PC12 cells, in which the major two proteins in whole-cell lysates were 43 and $60 \mathrm{kDa}$ (Fig. $7 A$, right two lanes). We concluded that the 43 and $60 \mathrm{kDa}$ substrates correspond to MAP II kinase and to pp60 ${ }^{\mathrm{c}-\mathrm{src}}$ protein tyrosine kinase, respectively (Fantl et al., 1993) (Fig. 7A). To verify pp60 ${ }^{\text {c-src }}$, the kinase was precipitated from whole-cell lysates with the monoclonal antibody against pp $60^{\mathrm{v}-\mathrm{src}}$ and detected by Western blotting against phosphotyrosine using RC20 (Fig. $7 B$ ). The phosphotyrosine analysis revealed a 2.5 -fold $(n=3)$ increase in tyrosine phosphorylation associated with the src kinase after stimulation with $25 \mathrm{~nm}$ bradykinin (Fig. 7B, right). Notably, bradykinin caused tyrosine phosphorylation of pp60 $0^{\mathrm{c}-\mathrm{src}}$ already at picomolar concentrations (Fig. 7B, middle) in which also F-actin loss occurred.

The $68 \mathrm{kDa}$ protein that co-precipitated with pp60 ${ }^{\mathrm{c}-\mathrm{src}}$ corresponded to paxillin, as judged from Western blotting against anti-paxillin antibodies (Fig. 7B, bottom lanes). Paxillin was originally found as a major tyrosine-phosphorylated protein in v-srctransformed cells (Glenney and Zokas, 1989). It is highly abundant at focal adhesion points of fibroblasts in which F-actin stress fibers are attached (Turner et al., 1990). We further analyzed bradykinin-induced tyrosine phosphorylation of paxillin in NGFdifferentiated PC12 cells. Phosphorylation of paxillin was increased 2.5-fold $(n=3)$ and 3.5-fold $(n=3)$ after $5 \mathrm{~min}$ of stimulation with $25 \mathrm{pm}$ and $25 \mathrm{~nm}$ bradykinin, respectively (Fig. $7 C)$. The response was completely inhibited in presence of the $\mathrm{B}_{2}$ receptor antagonist ( $\beta$-(2-thienyl)-Ala $\left.{ }^{5,8}, \mathrm{D}-\mathrm{Phe}^{7}\right)$-bradykinin. The antagonist itself $(1 \mu \mathrm{M})$ showed no intrinsic agonistic activity. Therefore, we concluded that the observed tyrosine phosphorylation of paxillin in PC12 cells is mediated via $\mathrm{B}_{2}$ receptors. As shown above, bradykinin-induced growth cone collapse was inhibited by $100 \mu \mathrm{M}$ genistein (Fig. 6). At the same concentration, genistein inhibited bradykinin-induced tyrosine phosphorylation by $75 \%(n=3)($ Fig. $7 D)$.

\section{Distribution of paxillin in PC12 neurites}

Paxillin has been localized in retinoic acid-differentiated $\mathrm{SH}$ SY5Y cells in which processes extended from the cell body and in neuritic growth cones (Leventhal and Feldman, 1996). Because the biochemical analysis of paxillin was performed using whole- 

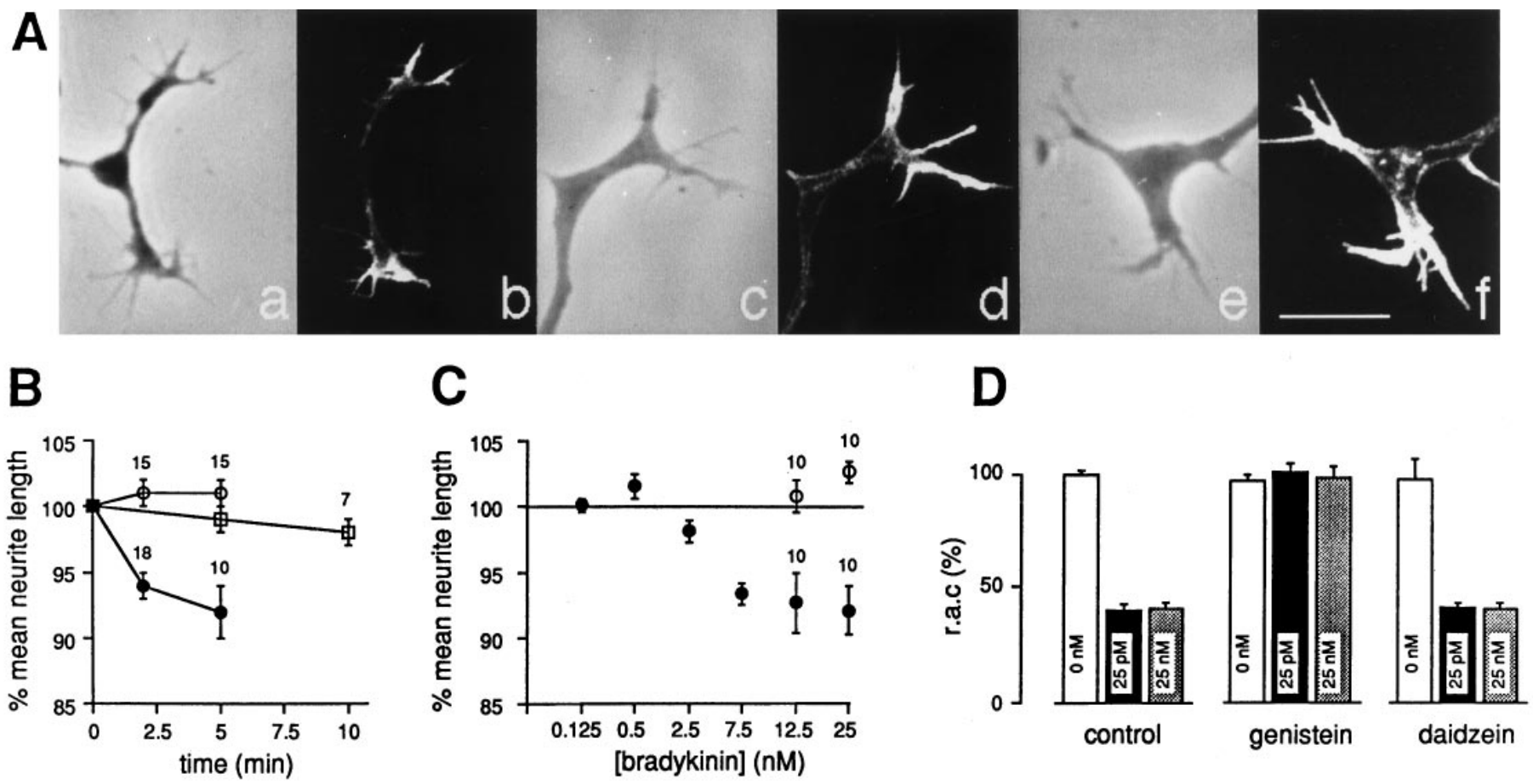

Figure 6. Inhibition of bradykinin-induced growth cone collapse by the tyrosine kinase inhibitor genistein. $A$, Phase-contrast images and the corresponding rhodamine phalloidin stain of growth cones after cell fixation. Cells were treated previously. $a, b$, Control; $c, d$, genistein ( $100 \mu \mathrm{M}, 15$ min in culture medium); $e, f$, bradykinin $(50 \mathrm{~nm}, 5 \mathrm{~min}$ ) plus genistein preincubation. Scale bar, $10 \mu \mathrm{m}$. $B$, Dependence of neurite length on genistein (100 $\mu \mathrm{M})$ and bradykinin. Cells kept in HEPES-buffered culture medium showed a marginal change in neurite length during incubation with genistein at RT for 5-10 min (open squares). Bradykinin (25 nM) induced about 8\% reduction in neurite length ( filled circles; also see Fig. 1C). Retraction was blocked in genistein-pretreated cells (open circles). The neurite length after 10 min preincubation with genistein was taken as $100 \%$. $C$, Inhibition of bradykinin-induced neurite retraction by genistein. Mean neurite length ( filled circles; $n=10$ ) was measured on digitized pictures after a 5 min exposure to increasing concentrations of bradykinin. A $100 \mu \mathrm{M}$ concentration of genistein inhibited the response of 12.5 and 25 nM bradykinin, respectively. $D$, Inhibition of bradykinin-induced F-actin loss by genistein. Cells were preincubated with $100 \mu \mathrm{M}$ genistein or $100 \mu \mathrm{M}$ daidzein for 15 min. The r.a.c. was determined after bath application of $0 \mathrm{~nm}$ bradykinin (open columns), $25 \mathrm{pm}$ bradykinin (filled columns), and $25 \mathrm{~nm}$ bradykinin (hatched columns).

cell lysates of NGF-treated PC12 cells, we confirmed the expression of paxillin in PC12 cell growth cones. Figure 8 compares the distribution of paxillin in undifferentiated PC12 cells, PC12 growth cones and neurites, and human foreskin fibroblasts, respectively. Cells were immunostained using the same antibody as for the immunoprecipitation. F-actin distribution at focal adhesion sites of fibroblasts was compared with F-actin-containing filopodia in PC12 growth cones. Fibroblast cells showed intense streaky spots at the initiation sites of F-actin-containing stress fibers (Fig. 8C,D). By comparison, undifferentiated PC12 cells showed a punctate staining that was most intense at the cone-like endings of the cell bodies (Fig. 8F). In differentiated PC12 cells, punctate staining of paxillin was observed along $\mathrm{PC} 12$ neurites and in the growth cones (Fig. 8J). Paxillin showed a high abundance in growth cones that supports the notion for a putative involvement in the bradykinin-induced effects at the growth cone proper. Growth cone diameter is comparable in size to the distance of two side-by side located focal adhesion points in fibroblasts. In comparison with fibroblasts, no clear localization of paxillin was observed at the initiation sites of F-actin-containing filopodia (Fig. 8G,H). However, paxillin was clearly detected at sites devoid of any F-actin and vice versa. It is tempting to speculate that paxillin in PC12 neurites is localized to point contacts that differ from their non-neuronal counterpart, the focal contacts of fibroblasts (McKerracher et al., 1996).

\section{DISCUSSION}

We studied bradykinin-induced growth cone collapse of NGFinduced PC12 neurites to gain insight into the molecular events of growth cone mobility by an extracellular signal. The relative F-actin content in single growth cones was measured after cell fixation by means of a double-labeling technique adapted from Fan et al. (1993) using confocal microscopy. Surprisingly, bradykinin caused F-actin loss in growth cone filopodia already at picomolar concentrations. Neurite retraction was evoked by bradykinin at nanomolar concentrations at which simultaneous $\mathrm{Ca}^{2+}$ release occurred. The observed effects are mediated by $\mathrm{B}_{2}$ receptors. Furthermore, we found that the nonreceptor proteintyrosine kinase $\mathrm{pp} 60^{\mathrm{c}-\mathrm{src}}$ and the cytoskeleton-associated protein paxillin were tyrosine-phosphorylated during these cellular events.

Our data obtained with different bradykinin derivatives argue that $\mathrm{B}_{2}$ receptors are responsible for the studied effects and that they are not only attributable to an unspecific effect of the added peptide. Bradykinin showed a $>1000$-fold difference in potency between induction of $\mathrm{F}$-actin loss $\left(\mathrm{EC}_{50}=1.6 \mathrm{pM}\right)$ and activation of the phosphoinositide second messenger pathway $\left(\mathrm{EC}_{50}=8.1\right.$ $\mathrm{nM})$, respectively. The $\mathrm{EC}_{50}$ value for bradykinin-induced $\mathrm{Ca}^{2+}$ release measured in single growth cones was similar to the $\mathrm{EC}_{50}$ value (1.6 nM) measured in undifferentiated PC12 cell bodies (Fasolato et al., 1988). We assume that $B_{2}$ receptors that have 

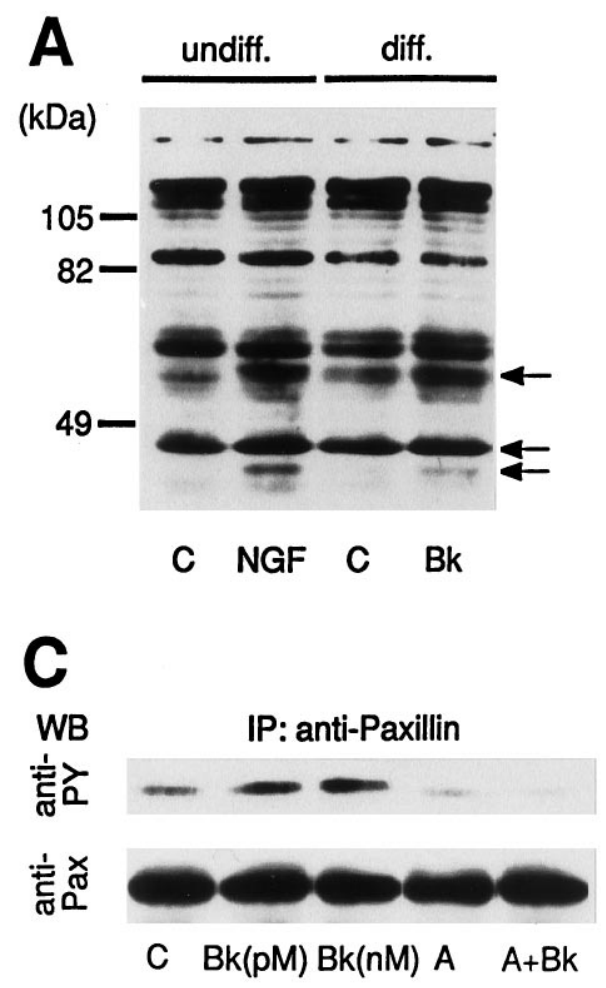
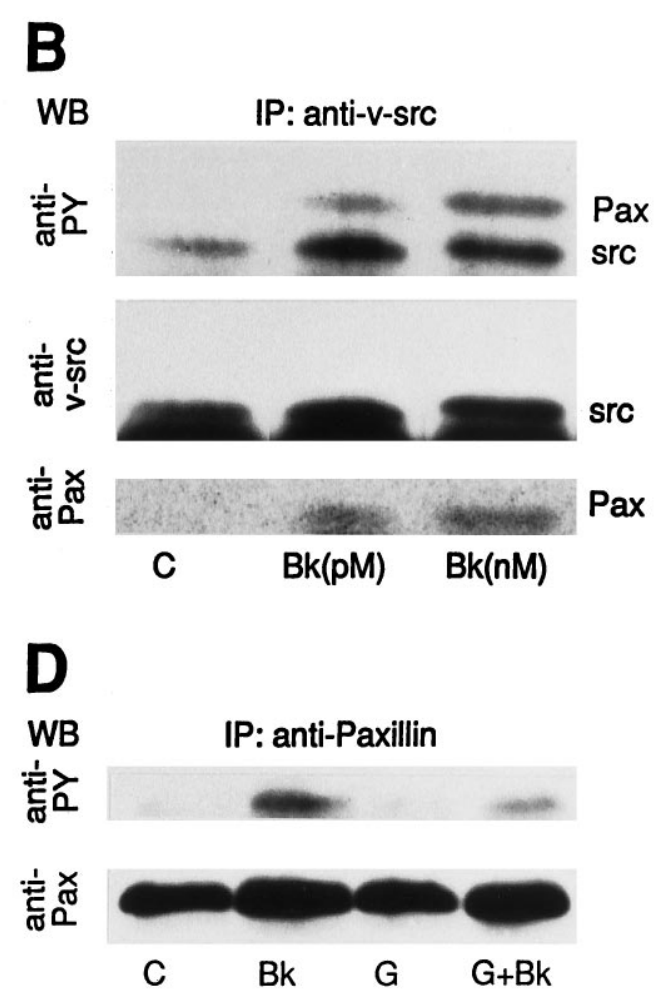

Figure 7. Bradykinin-induced tyrosine phosphorylation of NGF-differentiated PC12 cells. A, Protein tyrosine phosphorylation pattern of whole-cell lysates. Triton X-100 cell lysates were separated on $10 \%$ SDS-polyacrylamide gels and immunoblotted with antiphosphotyrosine antibody. First lane, Untreated PC12 cells; second lane, PC12 cells after 15 min stimulation with $100 \mathrm{ng} / \mathrm{ml} \mathrm{NGF}$; third lane, differentiated PC12 cells; fourth lane, differentiated PC12 cells stimulated with $25 \mathrm{~nm}$ bradykinin for $5 \mathrm{~min}$. Arrows point to tyrosine-phosphorylated proteins of 60 , 46 , and $43 \mathrm{kDa}$. $B$, Tyrosine phosphorylation of $\mathrm{pp} 60^{\mathrm{c}-\mathrm{src}}$. Cell lysates of NGF-differentiated PC12 cells were immunoprecipitated with anti-v-src antibodies after bradykinin treatment for 5 min. First lane, Control; second lane, 25 pM bradykinin; third lane, $25 \mathrm{~nm}$ bradykinin. Precipitated proteins were separated on $10 \%$ SDS-polyacrylamide gels and immunoblotted in sequential order with anti-phosphotyrosine, anti-v-src, and anti-paxillin antibodies. C, Pharmacology of bradykinin-induced tyrosine phosphorylation. Lysates were immunoprecipitated with anti-paxillin antibodies after bradykinin treatment. First lane, Control; second lane, 25 pm bradykinin; third lane, $25 \mathrm{nM}$ bradykinin;

fourth lane, $1 \mu \mathrm{M}\left(\beta\right.$-(2-thienyl)-Ala $\left.{ }^{5,8}, \mathrm{D}-\mathrm{Phe}^{7}\right)$-bradykinin $(A)$; fifth lane, $1 \mu \mathrm{M}\left(\beta\right.$-(2-thienyl)-Ala $\left.{ }^{5,8}, \mathrm{D}-\mathrm{Phe}^{7}\right)$-bradykinin $(G)$ plus $25 \mathrm{nM}$ bradykinin. Proteins separated on SDS-PAGE were immunoblotted with anti-phosphotyrosine and anti-paxillin antibodies. $D$, Inhibition of tyrosine phosphorylation by genistein. First lane, Control; second lane, $25 \mathrm{~nm}$ bradykinin; third lane, $100 \mu \mathrm{M}$ genistein; fourth lane, $100 \mu \mathrm{M}$ genistein plus $25 \mathrm{~nm}$ bradykinin. Bradykinin was added after preincubation with genistein $(15 \mathrm{~min})$ for $5 \mathrm{~min}$. Data are representative of three different experiments. undiff., Undifferentiated; diff., differentiated; $C$, control; $B k$, bradykinin; $P Y$, phosphotyrosine.

been identified at the molecular level in PC12 cells (Nardone and Hogan, 1994) are involved in the $\mathrm{Ca}^{2+}$ responses. It is more difficult to explain why some effects are already evoked at picomolar concentrations of bradykinin. There is pharmacological evidence for the existence of more than one $\mathrm{B}_{2}$ receptor type (Plevin and Owen, 1988). Therefore, other $B_{2}$ receptors may be responsible for the observed PC12 growth cone collapse. Fibroblasts transfected with the Ha-ras oncogene display two binding sites for bradykinin; high-affinity binding sites $\left(\mathrm{K}_{\mathrm{d}}=4.9 \mathrm{nM}\right)$ co-exist with very high-affinity sites $\left(\mathrm{K}_{\mathrm{d}}=2.7 \mathrm{pM}\right)$ (Roberts and Gullick, 1989). Because formation of PC12 neurites depends on active ras protein (D'Arcangelo and Halegoua, 1993), this small GTP-binding protein could be responsible for expression of another $\mathrm{B}_{2}$ bradykinin receptor gene during NGF-induced differentiation. An alternative explanation is that at the growth cone level a better coupling between receptor and G-protein exists (Wakelam et al., 1986).

In PC12 cells, it is well established that bradykinin acts by binding to $G$-protein-coupled $B_{2}$ receptors, which leads to the formation of $\mathrm{IP}_{3}$ and subsequent $\mathrm{Ca}^{2+}$ release (Fasolato et al., 1988). In view of the intracellular $\mathrm{Ca}^{2+}$ mobilization, we tested effects of $\left[\mathrm{Ca}^{2+}\right]_{\mathrm{i}}$ rises on filopodial F-actin. Our results confirmed that filopodial F-actin depolymerizes in the growth cones during high $\left[\mathrm{Ca}^{2+}\right]_{\mathrm{i}}$ levels, as described for other cell types (Neely and Gesemann, 1994; Rehder and Kater, 1996). Nevertheless, increase of cytosolic $\mathrm{Ca}^{2+}$ concentration is not an obligatory signal in $\mathrm{PC} 12$ growth cones during bradykinin-induced F-actin loss and growth cone retraction, because the morphological changes occurred even after depletion of $\mathrm{Ca}^{2+}$ stores, pre- vention of $\mathrm{Ca}^{2+}$ influx, or buffering $\mathrm{Ca}^{2+}$ responses by BAPTA. In addition, bradykinin caused $\mathrm{F}$-actin loss at concentrations much lower than those required for $\mathrm{IP}_{3}$-induced $\mathrm{Ca}^{2+}$ release.

Experiments with genistein, a nonselective tyrosine kinase inhibitor, suggested that tyrosine phosphorylation is involved in the bradykinin-induced growth cone collapse. Phosphotyrosine protein analysis showed that bradykinin stimulated tyrosine phosphorylation of pp60 ${ }^{\mathrm{c}-\mathrm{src}}$ and paxillin. Similar to the F-actin loss, phosphorylation was evoked already at picomolar concentrations of the agonist. Our data show that the nonreceptor PTK pp60 ${ }^{\text {c-src }}$ that is concentrated in nerve growth cones of developing and regenerating neurons (Maness et al., 1988; Ignelzi et al. 1992) can be activated through activation of extracellularly applied bradykinin. Inhibition of pp60 ${ }^{\mathrm{c}-\mathrm{src}}$ present in PC12 growth cones (Miller et al., 1993) by genistein is also in good agreement with our results. Therefore, the pp $60^{\mathrm{c}-\mathrm{src}}$ may be involved in bradykinininduced growth cone collapse.

The cytoskeleton-associated protein paxillin was detected as a main substrate of pp60 $0^{\text {c-src }}$ kinase in bradykinin action. Paxillin was originally identified as a major tyrosine-phosphorylated protein in Rous sarcoma virus-transformed fibroblasts in which v-src is highly expressed (Glenney and Zokas, 1989). Here, we were able to show that bradykinin induces tyrosine phosphorylation of paxillin in NGF-differentiated PC12 cells maybe during a cellular event affecting growth cone mobility. Tyrosine phosphorylation of paxillin by NGF has been shown previously in undifferentiated PC12h cells (Khan et al., 1995). In addition, bradykinin-evoked tyrosine phosphorylation of paxillin has been described in Swiss 3 T3 cells by the nonreceptor PTK focal adhesion kinase 
Figure 8. Localization of paxillin in fibroblasts, PC12 cells, and PC12 neurites. Fibroblasts were grown on uncoated glass coverslips, and PC12 cells were grown on laminin- and poly-L-lysine-coated glass coverslips for $4 \mathrm{~d}$. Fixed cells were immunostained for paxillin with FITC-labeled Fab fragments and for F-actin with RP. Cells were viewed by confocal microscopy. The horizontal bars represent $10 \mu \mathrm{m}$. $A$, Bright-field image of a fibroblast. $B$, Distribution of paxillin in a fibroblast at focal contacts. $C$, Stained F-actin stress fibers in a fibroblast. $D$, Distribution of paxillin in fibroblast co-localized with F-actin (compare with $C$ ). E, Bright-field image of untreated PC12 cells. F, Distribution of paxillin in untreated $\mathrm{PC} 12$ cells at coneshaped endings. $G$, Stained F-actin in PC12 cell growth cone. $H$, Distribution of paxillin in PC12 cell growth cone. The protein is present at the cone center and absent from filopodia. I, Bright-field image of a PC12 neurite. J, Distribution of paxillin in PC12 neurite and growth cone.
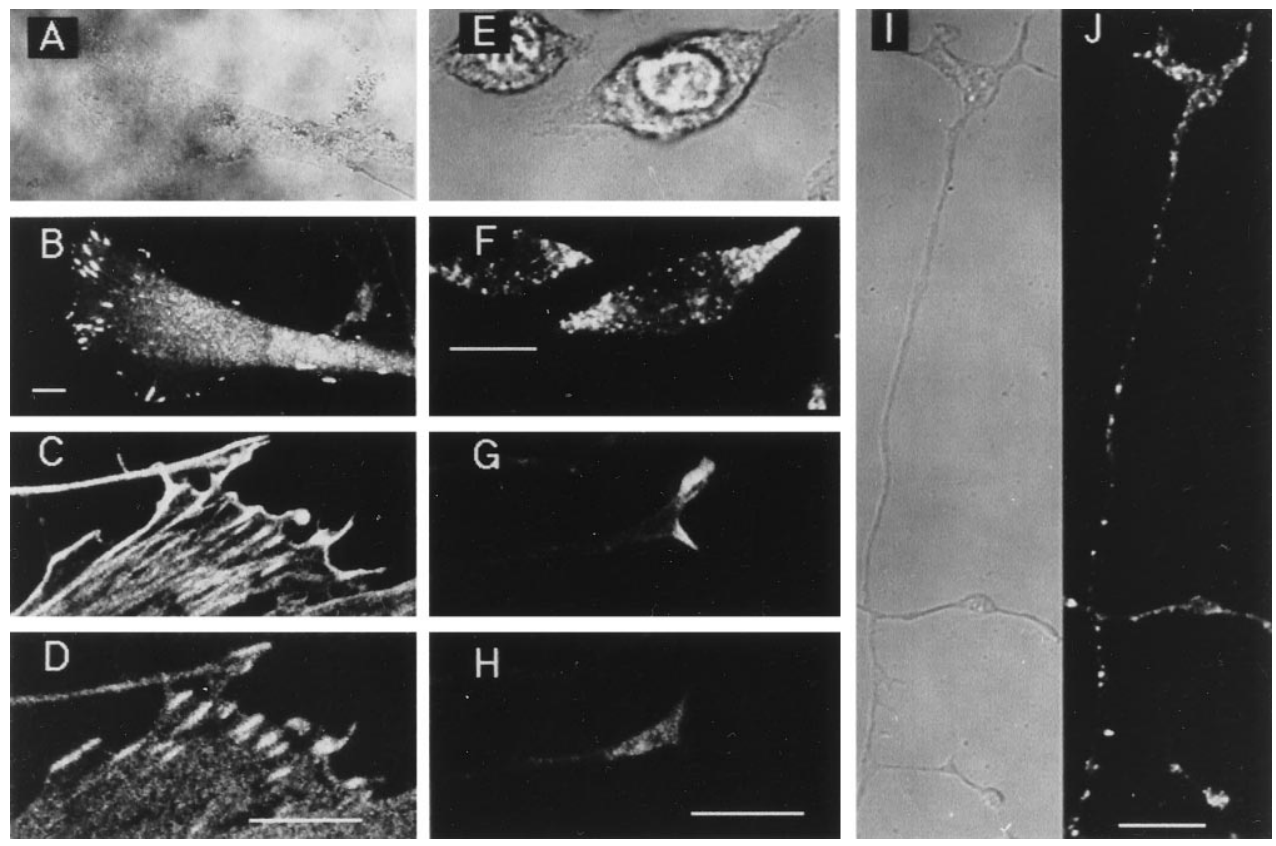

pp125 FAK (Leeb-Lundberg et al., 1994). Therefore, paxillin seems to be a ubiquitous substrate for various tyrosine kinases depending on cell type and agonist.

Immunocytochemistry experiments showed that paxillin is expressed in PC12 neurites and growth cones. A similar distribution of paxillin has been shown in retinoic acid-differentiated $\mathrm{SH}$ SY5Y cells, in which paxillin was also localized to growth cones (Leventhal and Feldman, 1996). Although localization of paxillin at initiation sites of F-actin stress fibers in fibroblasts was clearly verified, we were unable to observe clear localization of paxillin at proximal endings of F-actin filaments in PC12 growth cones. Instead, paxillin was distributed along neuritic shafts and showed a high abundance in growth cones. This argues for a different organization of paxillin-containing sites in PC12 neurites compared with fibroblast cells. The punctate distribution of paxillin may localize to intermediate, dynamic contact points rather than to focal contacts as seen in fibroblasts (Gomez et al., 1996; McKerracher et al., 1996).

A significant fraction of tyrosine-phosphorylated paxillin molecules seems to associate with pp $60^{\text {c-src }}$ as a result of bradykininevoked responses, as judged from co-precipitation of paxillin with pp $60^{\mathrm{c}-\mathrm{src}}$ when using antibodies to the tyrosine kinase. Similarly, pp60 $0^{\mathrm{c}-\mathrm{src}}$ is involved in bradykinin-dependent tyrosine phosphorylation of paxillin in human foreskin fibroblasts (Lee and Villereal, 1996). At present it is unclear how these two proteins associate because of activation of the bradykinin receptor. The nonreceptor PTK PYK2 (Lev et al., 1995) has been suggested as a possible link between the G-protein-coupled receptor and srcrelated tyrosine phosphorylation, because micromolar concentration of bradykinin causes activation of the src-MAP kinase pathway via PYK2 in undifferentiated PC12 cells (Dikic et al., 1996). However, it has not yet been determined whether paxillin can be phosphorylated by the PYK2-src-linked pathway in PC12 cells. Furthermore, a $\left[\mathrm{Ca}^{2+}\right]_{\mathrm{i}}$ rise is required for PYK2 activation. However, a $\mathrm{Ca}^{2+}$ response is not obligatory for the bradykininevoked phosphorylation as discussed above.

Various signaling molecules have been demonstrated to influence growth cone mobility and guidance (Goodman, 1996). Our data describe such an activity for bradykinin in an in vitro system that allowed analysis of several cellular events. Evidence is provided that tyrosine phosphorylation plays an important step in this cellular mechanism. Our data support the notion that pp60 $0^{\mathrm{c}-\mathrm{src}}$ kinase activity is important for cellular mechanisms affecting the mobility of PC12 growth cones. The physiological significance of the tyrosine phosphorylation of paxillin is poorly understood. We favor its role to present extra docking sites for kinases (Khan et al., 1996), whereby the tyrosine-phosphorylated forms of paxillin associate with src homology 2 domains of other protein tyrosine kinases and constitute a platform for them to act closer to other cytoskeleton-associated components such as vinculin (Turner et al., 1990). Therefore, paxillin located at the inner cell surface membrane may play an important function in translating protein kinase activity into structural rearrangements of the cytoskeleton as being present in growth cone movement.

In conclusion, our data show that bradykinin causes a small growth cone collapse of NGF-differentiated PC12 cells mediated by $B_{2}$ receptors. The G-protein receptor-linked signal transduction shows crosstalk to tyrosine kinase activation. In addition, the cytoskeleton-associated protein paxillin constitutes a putative protein involved in the dynamic reorganization of neurite morphology.

\section{REFERENCES}

Akiyama T, Ishida J, Nakagawa S, Ogawara H, Watanabe S-I, Itoh N, Shibuya M, Fukami Y (1987) Genistein, a specific inhibitor of tyrosine-specific protein kinases. J Biol Chem 262:5592-5595.

Aletta JM, Greene LA (1988) Growth cone configuration and advance: a time-lapse study using video-enhanced differential interference contrast microscopy. J Neurosci 8:1425-1435.

Brake AJ, Wagenbach MJ, Julius D (1994) New structural motif for ligand-gated ion channels defined by an ionotropic ATP receptor. Nature 371:519-523.

Cachelin AB, Rust G (1994) Unusual pharmacology of (+)tubocurarine with rat neuronal acetylcholine receptors containing $\beta 4$ subunits. Mol Pharmacol 46:1168-1174.

Challacombe JF, Snow DM, Letourneau PC (1996) Role of the cytoskeleton in growth cone motility and axonal elongation. Semin Neurosci 8:67-80.

D’Arcangelo G, Halegoua S (1993) A branched signaling pathway for 
nerve growth factor is revealed by $\mathrm{src}^{-}$, ras, and raf-mediated gene inductions. Mol Cell Biol 13:3146-3155.

Dikic I, Tokiwa G, Lev S, Courtneidge SA, Schlessinger J (1996) A role for PYK2 and Src in linking G-protein-coupled receptors with MAP kinase activation. Nature 383:547-550.

Fan J, Mansield GS, Redmond T, Gordon-Weeks PR, Raper JA (1993) The organization of F-actin and microtubules in growth cones exposed to a brain-derived collapsing factor. J Cell Biol 121:867-878.

Fantl WJ, Johnson DE, Williams LT (1993) Signalling by receptor tyrosine kinases. Annu Rev Biochem 62:453-481.

Farmer SG, Burch RM (1992) Biochemical and molecular pharmacology of kinin receptors. Annu Rev Pharmacol Toxicol 32:511-536.

Fasolato C, Pandiella A, Meldolesi J, Pozzan T (1988) Generation of inositol phosphates, cytosolic $\mathrm{Ca}^{2+}$, and ionic fluxes in $\mathrm{PC} 12$ cells treated with bradykinin. J Biol Chem 263:17350-17359.

Glenney Jr JR, Zokas L (1989) Novel tyrosine kinase substrates from Rous sarcoma virus-transformed cells are present in the membrane skeleton. J Cell Biol 108:2401-2408.

Gomez TM, Roche FK, Letourneau PC (1996) Chick sensory neuronal growth cones distinguish fibronectin from laminin by making substratum contacts that resemble focal contacts. J Neurobiol 29:18-34.

Goodman CS (1996) Mechanisms and molecules that control growth cone guidance. Annu Rev Neurosci 19:341-377.

Greene LA, Tischler AS (1976) Establishment of a noradrenergic clonal cell line of rat adrenal pheochromocytoma cells which respond to nerve growth factor. Proc Natl Acad Sci USA 73:2424-2428.

Holland SJ, Gale NW, Mbamalu G, Yancopoulos GD, Henkemeyer M, Pawson T (1996) Bidirectional signalling through the EPH-family receptor Nuk and its transmembrane ligands. Nature 383:722-725.

Ignelzi MA, Padilla SS, Warder DE, Maness PF (1992) Altered expression of pp60 $0^{\text {c-src }}$ induced by peripheral nerve injury. J Comp Neurol 315:171-177.

Ignelzi MA, Miller DR, Soriano P, Maness PF (1994) Impaired neurite outgrowth of src-minus cerebellar neurons on the cell adhesion molecule L1. Neuron 12:873-884.

Ivins JK, Raper JA, Pittman RN (1991) Intracellular calcium levels do not change during contact-mediated collapse of chick DRG growth cone structure. J Neurosci 11:1597-1608.

Keynes RJ, Cook GMW (1995) Repulsive and inhibitory signals. Curr Opin Neurobiol 5:75-82.

Khan MA, Okumura N, Okada M, Kobayashi S, Nakagawa H (1995) Nerve growth factor stimulates tyrosine phosphorylation of paxillin in PC12h cells. FEBS Lett 362:201-204.

Khan MA, Okumura N, Okada M (1996) Depolarization-induced tyrosine phosphorylation of paxillin in $\mathrm{PC} 12 \mathrm{~h}$ cells. Eur $\mathrm{J}$ Biochem 235:579-584.

Lammek B, Wang YX, Gavras I, Gavras H (1991) A novel bradykinin antagonist with improved properties. J Pharm Pharmacol 43:887-888.

Lankford KL, Letourneau PC (1989) Evidence that calcium may control neurite outgrowth by regulating the stability of actin filaments. J Cell Biol 109:1229-1243.

Lee K, Villereal ML (1996) Tyrosine phosphorylation and activation of pp60 ${ }^{\text {c-src }}$ and pp125 $5^{\text {FAK }}$ in bradykinin-stimulated fibroblasts. Am J Physiol 270:C1430-C1437.

Leeb-Lundberg LM, Song X-H, Mathis SA (1994) Focal adhesionassociated proteins pp125 $5^{\text {FAK }}$ and paxillin are substrates for bradykinin-stimulated tyrosine phosphorylation in Swiss 3T3 cells. J Biol Chem 269:24328-24334.

Lev S, Moreno, H, Martinez R, Canoll P, Peles E, Musacchio JM, Plowman GD, Rudy B, Schlessinger J (1995) Protein tyrosine kinase PYK2 involved in $\mathrm{Ca}^{2+}$-induced regulation of ion channel and MAP kinase functions. Nature 376:737-745.

Leventhal PS, Feldman EL (1996) Tyrosine phosphorylation and enhanced expression of paxillin during neuronal differentiation in vitro. J Biol Chem 271:5957-5960.

Luo Y, Raible D, Raper J (1993) Collapsin: a protein in brain that induces the collapse and paralysis of neuronal growth cones. Cell 75:217-227.

Maness PF, Aubry M, Shores CG, Frame L, Pfenninger KH (1988) src gene product in developing rat brain is enriched in nerve growth cone membranes. Proc Natl Acad Sci USA 85:5001-5005.
McKerracher L, Chamoux M, Arregui CO (1996) Role of laminin and integrin interactions in growth cone guidance. Mol Neurobiol 12:95-116.

Miller DR, Lee GM, Maness PF (1993) Increased neurite outgrowth induced by inhibition of protein tyrosine kinase activity in $\mathrm{PC} 12$ pheochromocytoma cells. J Neurochem 60:2134-2144.

Nardone J, Hogan PG (1994) Delineation of a region in the $\mathrm{B}_{2}$ bradykinin receptor that is essential for high-affinity agonist binding. Proc Natl Acad Sci USA 91:4417-4421.

Neely MD, Gesemann M (1994) Disruption of microfilaments in growth cones following depolarisation and calcium influx. $\mathrm{J}$ Neurosci 14:7511-7520.

Okabe S, Hirokawa N (1991) Actin dynamics in growth cones. J Neurosci 11:1918-1929.

Pandiella A, Meldolesi J (1989) Reinforcement of signal generation at $\mathrm{B}_{2}$ bradykinin receptors by insulin, epidermal growth factors, and other growth factors. J Biol Chem 264:3122-3130.

Pasquale EB, Deerinck TJ, Singer SJ, Ellisman MH (1992) Cek5, a membrane receptor-type tyrosine kinase, is in neurons of the embryonic and postnatal avian brain. J Neurosci 12:3956-3967.

Plevin R, Owen P (1988) Multiple $\mathrm{B}_{2}$ kinin receptors in mammalian tissues. Trends Pharmacol Sci 9:387-389.

Reber BFX, Schindelholz B (1996) Detection of a trigger zone of bradykinin-induced fast $\mathrm{Ca}^{2+}$ waves in PC12 neurites. Pflügers Arch 432:893-903.

Reber BFX, Neuhaus R, Reuter H (1992) Activation of different pathways for calcium elevation by bradykinin and ATP in rat pheochromocytoma (PC12) cells. Pflügers Arch 420:213-218.

Rehder V, Kater SB (1996) Filopodia on neuronal growth cones: multifunctional structures with sensory and motor capabilities. Semin Neurosci $8: 81-88$.

Roberts RA, Gullick WJ (1989) Bradykinin receptor number and sensitivity to ligand stimulation of mitogenesis is increased by expression of a mutant ras oncogene. J Cell Sci 94:527-535.

Sawin KE, Theriot JA, Mitchison TJ (1993) Photoactivation of fluorescence as a probe for cytoskeletal dynamics in mitosis and cell motility. In: Fluorescent and luminescent probes for biological activity (Mason WT, ed), pp 405-419. San Diego: Academic.

Schild HO (1947) pA, a new scale for measurement of drug antagonism. Br J Pharmacol 2:541-561.

Schindelholz B, Reber BFX (1996) Bradykinin-induced growth cone collapse of rat pheochromocytoma (PC12) cells. Experientia 52:A31.

Schwab ME, Kapf hammer JP, Bandtlow CE (1993) Inhibitors of neurite growth. Annu Rev Neurosci 16:565-595.

Sobue K, Kanda K (1988) Localization of pp60 ${ }^{\text {c-src }}$ in growth cone of PC12 cell. Biochem Biophys Res Commun 157:1383-1389.

Steranka LR, Farmer SG, Burch RM (1989) Antagonists of $B_{2}$ bradykinin receptors. FASEB J 3:2019-2025.

Symons MH, Mitchison TJ (1991) Control of actin polymerization in live and permeabilized fibroblasts. J Cell Biol 114:503-513.

Tessier-Lavigne M, Goodman CS (1996) The molecular biology of axon guidance. Science 274:1123-1133.

Thastrup O, Culen, PJ, Drobak B, Hanley MR, Dawson AP (1990) Thapsigargin, a tumor promoter, discharges intracellular $\mathrm{Ca}^{2+}$ stores by specific inhibition of the endoplasmic reticulum $\mathrm{Ca}^{2+}$-ATPase. Proc Natl Acad Sci USA 87:2466-2470.

Tigyi G, Fischer DJ, Sebök A, Yang C, Dyer DL, Miledi R (1996) Lysophosphatidic acid-induced neurite retraction in PC12 cells: control by phosphoinositide- $\mathrm{Ca}^{2+}$ signaling and Rho. J Neurochem 66:537-548.

Turner CE, Miller JT (1994) Primary sequence of paxillin contains putative $\mathrm{SH} 2$ and $\mathrm{SH} 3$ domain binding motifs and multiple LIM domains: identification of a vinculin and pp $125^{\text {FAK }}$-binding region. J Cell Sci 107:1583-1591.

Turner CE, Glenney JR, Burridge K (1990) Paxillin: a new vinculinbinding protein present in focal adhesions. J Cell Biol 111:1059-1068.

Wakelam MJO, Davies SA, Houslay MD, McKay I, Marshall CJ, Hall A (1986) Normal p $21^{\text {N-ras }}$ couples bombesin and other growth factors to inositol phosphate production. Nature 323:173-176. 